\title{
Identification of Phenolic Compounds in Australian-Grown Bell Peppers by Liquid Chromatography Coupled with Electrospray Ionization-Quadrupole-Time-of-Flight-Mass Spectrometry and Estimation of Their Antioxidant Potential
}

\author{
Zexing Leng, Biming Zhong, Hanjing Wu, Ziyao Liu, Abdur Rauf,* Sami Bawazeer, \\ and Hafiz Ansar Rasul Suleria*
}

Cite This: https://doi.org/10.1021/acsomega.1c06532

Read Online

ACCESS |

Wll Metrics \& More

回 Article Recommendations

Supporting Information

ABSTRACT: Bell peppers are widely considered as healthy foods that can provide people with various phytochemicals, especially phenolic compounds, which contribute to the antioxidant property of bell peppers. Nevertheless, the acknowledgment of phenolic compounds in bell peppers is still limited. Therefore, this study aimed to determine the phenolic content and the antioxidant potential in pulps and seeds of different bell peppers (green, yellow, and red) by several in vitro assays followed by the characterization and quantification of individual phenolics using liquid chromatography coupled with electrospray ionizationquadrupole-time-of-flight-mass spectrometry (LC-ESI-QTOF-

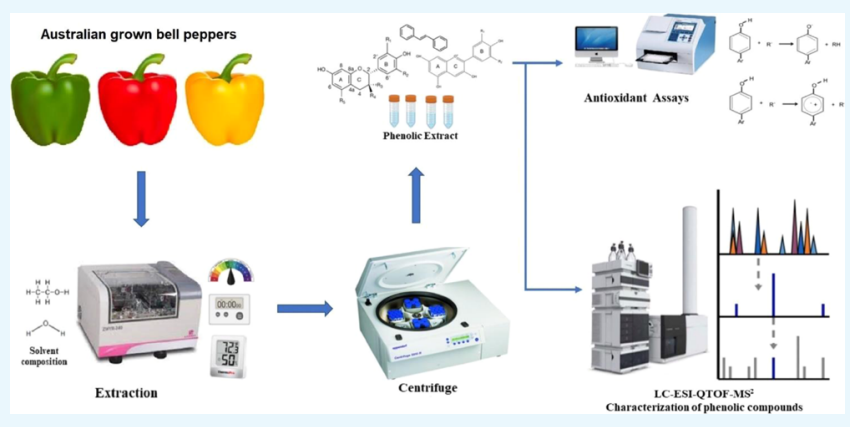
MS/MS) and high-performance liquid chromatography photodiode array (HPLC-PDA) quantification, respectively. The captured results showed that the pulp of red bell peppers exhibited the highest phenolic content in the total polyphenol content $\left(1.03 \pm 0.07 \mathrm{mg} \mathrm{GAE} / \mathrm{g}_{\text {f.w. }}\right)$, total flavonoid content $(137.43 \pm 6.35 \mu \mathrm{g}$ QE/ $\left.\mathrm{g}_{\text {f.w. }}\right)$, and total tannin content $\left(0.22 \pm 0.01 \mathrm{mg} \mathrm{CE} / \mathrm{g}_{\text {f.w. }}\right)$ as well as the most antioxidant potential in all antioxidant capacity estimation assays including total antioxidant capacity $\left(3.56 \pm 0.01 \mathrm{mg}\right.$ AAE $\left./ \mathrm{g}_{\mathrm{f} . \mathrm{w} .}\right), 2,2^{\prime}$-diphenyl-1-picrylhydrazyl (0.89 $\pm 0.01 \mathrm{mg}$ $\mathrm{AAE} / \mathrm{g}_{\text {f.w. }}$ ), 2,2'-azinobis-(3-ethylbenzothiazoline-6-sulfonic acid) $\left(1.36 \pm 0.12 \mathrm{mg} \mathrm{AAE} / \mathrm{g}_{\text {f.w. }}\right)$, and ferric reducing antioxidant power $\left(0.15 \pm 0.01 \mathrm{mg} \mathrm{AAE} / \mathrm{g}_{\text {f.w. }}\right)$. LC-ESI-QTOF-MS/MS isolated and identified a total of 59 phenolic compounds, including flavonoids (21), phenolic acids (20), other phenolic compounds (12), lignans (5), and stilbenes (1) in all samples. According to HPLC-PDA quantification, the seed portions showed a significantly higher amount of phenolic compounds. These findings indicated that the waste of bell peppers can be a potential source of phenolic compounds, which can be utilized as antioxidant ingredients in foods and nutritional products.

\section{INTRODUCTION}

Capsicums are typical economical crops belonging to the Solanaceae family and are mainly distributed in tropical and temperate areas. ${ }^{1}$ The global production of capsicums was over 11 million tons in 1990 and reached 28 million tons in $2009 .^{2}$ According to Australian Bureau of Statistics, the total capsicum (except chilies) production in Australia in 2015 was 38,579 tons and had risen to 49,038 tons in 2017. ${ }^{3,4}$ Generally, there are five popular species around the world: Capsicum annuum L., Capsicum baccatum L., Capsicum chinese Jacq., Capsicum frutescens L., and Capsicum pubescens, among which bell peppers (Capsicum annuum L.) are consumed globally as vegetables or processed into different products because of their beautiful color, impressive taste, and nutritional value., ${ }^{5,6}$ Bell peppers have many beneficial and pharmacological characteristics such as antioxidative, anti-inflammatory, and anticarcinogenic properties. ${ }^{7,8}$ These health-promoting properties are mainly related to the bioactive components including vitamins, carotenoids, and especially phenolic compounds. ${ }^{9}$

Phenolic compounds are the secondary metabolites that are widely found in plants. Generally, phenolic compounds contain one or more hydroxyl groups attached to an aromatic ring including simple types and polymers. ${ }^{10}$ These phenolic compounds are normally involved in defense responses in plants such as the insect-repellent property, resistance to ultraviolet interference, and protection against genetic mutations during the physiological activities of plants. ${ }^{11,12}$

Received: November 19, 2021

Accepted: January 10, 2022 
Table 1. Summary Table of Phytochemical and Antioxidant Assays in Green, Yellow, and Red Bell Capsicum Fruits ${ }^{a}$

\begin{tabular}{|c|c|c|c|c|c|c|}
\hline \multirow[b]{2}{*}{ sample } & \multicolumn{2}{|c|}{ green bell capsicum } & \multicolumn{2}{|c|}{ yellow bell capsicum } & \multicolumn{2}{|c|}{ red bell capsicum } \\
\hline & pulp & seed & pulp & seed & pulp & seed \\
\hline $\mathrm{TPC}\left(\mathrm{mg} \mathrm{GAE} / \mathrm{g}_{\text {f.w. }}\right)$ & $0.39 \pm 0.02^{c}$ & $0.43 \pm 0.01^{c}$ & $0.72 \pm 0.06^{b}$ & $0.52 \pm 0.02^{\mathrm{c}}$ & $1.03 \pm 0.07^{\mathrm{a}}$ & $0.53 \pm 0.03^{c}$ \\
\hline $\operatorname{TFC}\left(\mu \mathrm{g} \mathrm{QE} / \mathrm{g}_{\text {f.w. }}\right)$ & $30.21 \pm 2.36^{\mathrm{b}}$ & $4.98 \pm 0.07^{\mathrm{c}}$ & $14.93 \pm 0.27^{\mathrm{bc}}$ & $3.66 \pm 0.05^{\mathrm{c}}$ & $137.43 \pm 6.35^{\mathrm{a}}$ & $0.54 \pm 0.01^{c}$ \\
\hline TTC (mg CE $\left./ \mathrm{g}_{\text {f.w. }}\right)$ & $0.05 \pm 0.00^{\mathrm{d}}$ & $0.11 \pm 0.01^{\mathrm{bcd}}$ & $0.07 \pm 0.00^{\mathrm{cd}}$ & $0.13 \pm 0.01^{\mathrm{b}}$ & $0.22 \pm 0.01^{\mathrm{a}}$ & $0.12 \pm 0.00^{\mathrm{bc}}$ \\
\hline $\mathrm{TAC}\left(\mathrm{mg} \mathrm{AAE} / \mathrm{g}_{\text {f.w. }}\right)$ & $1.43 \pm 0.08^{c}$ & $0.76 \pm 0.00^{\mathrm{de}}$ & $2.46 \pm 0.03^{\mathrm{b}}$ & $0.88 \pm 0.01^{\mathrm{d}}$ & $3.56 \pm 0.01^{\mathrm{a}}$ & $0.58 \pm 0.03^{\mathrm{e}}$ \\
\hline $\mathrm{DPPH}\left(\mathrm{mg} \mathrm{AAE} / \mathrm{g}_{\mathrm{f} . \mathrm{w} .}\right)$ & $0.17 \pm 0.01^{c}$ & $0.12 \pm 0.01^{c}$ & $0.75 \pm 0.04^{\mathrm{b}}$ & $0.15 \pm 0.00^{c}$ & $0.89 \pm 0.01^{a}$ & $0.11 \pm 0.00^{c}$ \\
\hline ABTS (mg AAE $\left./ g_{\text {f.w. }}\right)$ & $0.49 \pm 0.02^{c}$ & $0.38 \pm 0.01^{\mathrm{c}}$ & $0.96 \pm 0.08^{\mathrm{b}}$ & $0.56 \pm 0.06^{\mathrm{c}}$ & $1.36 \pm 0.12^{\mathrm{a}}$ & $0.56 \pm 0.03^{\mathrm{c}}$ \\
\hline FRAP (mg AAE/g g f.w. $\left._{\text {. }}\right)$ & $0.02 \pm 0.00^{c}$ & $0.02 \pm 0.00^{\mathrm{bc}}$ & $0.10 \pm 0.00^{\mathrm{ab}}$ & $0.04 \pm 0.00^{\mathrm{bc}}$ & $0.15 \pm 0.01^{a}$ & $0.02 \pm 0.00^{c}$ \\
\hline
\end{tabular}

${ }^{a_{T}}$ The data are shown as mean \pm standard deviation $(n=3)$; Superscripts $\mathrm{a}, \mathrm{b}, \mathrm{c}, \mathrm{d}$, and e indicate the means in a row with significant difference $(p<$ 0.05 ) using one-way analysis of variance (ANOVA) and Tukey's test. GAE, gallic acid equivalents; QE, quercetin equivalents; CE, catechin equivalents; AAE, ascorbic acid equivalents; total phenolic content (TPC), total flavonoid content (TFC), total tannin content (TTC), total antioxidant content (TAC), 2,2-diphenyl-1-picrylhydrazyl (DPPH), 2,2-azinobis-(3-ethylbenzo-thiazoline-6-sulfonic) acid (ABTS+) and ferric reducing antioxidant power (FRAP); f.w., fresh weight.

Polyphenolics can be divided into several groups, including phenolic acids, flavonoids, lignans, and stilbenes, which can be extracted using different organic solvents. ${ }^{13,14}$ Phenolic compounds exhibit their antioxidant abilities through different mechanisms such as chelating metal ions, scavenging free radicals, and disintegrating peroxides. ${ }^{15}$ Commercially, polyphenols are regarded as the supplementary ingredients in human diets because of their superb antioxidant potentials. ${ }^{16}$

Previously, bell peppers were proved to be good sources of phenolic compounds with remarkable antioxidant potential by Blanco-Ríos et al. ${ }^{17}$ In the present study, polyphenolic contents in bell peppers were evaluated by various in vitro assays such as total polyphenol content (TPC), total flavonoid content (TFC), and total tannin content (TTC), while 2,2'-diphenyl1-picrylhydrazyl (DPPH), 2,2'-azinobis-(3-ethylbenzothiazoline-6-sulfonic acid) (ABTS), ferric reducing antioxidant power (FRAP), and total antioxidant capacity (TAC) were used to assess the antioxidant potentials. ${ }^{18,19}$ However, the colorimetric methods neither isolate nor quantify the individual phenolic compounds. High-performance liquid chromatography coupled with electrospray ionization-quadrupole-time-offlight-mass spectrometry (LC-ESI-QTOF-MS/MS) and highperformance liquid chromatography photodiode array (HPLCPDA) quantification are the effective techniques to characterize and quantify various phenolic compounds present in different food materials. ${ }^{20}$ Although some phenolic compounds have been identified in bell peppers through high-performance liquid chromatography (HPLC) such as quercetin and luteolin, $^{6}$ only a few research studies were related to Australian-grown bell peppers, and the contents and antioxidant capacities of these phenolic compounds in the bell peppers are still unclear.

The objectives of this research were: (a) to extract the polyphenols from different portions of bell peppers, (b) to compare the polyphenol contents and the antioxidant capacities in the bell pepper samples, and (c) to characterize and quantify individual phenolic compounds using LC-ESI-QTOF-MS/MS and HPLC-PDA. The outcome of the research could provide a comprehensive analysis of phenolic compounds in Australian-grown bell peppers for further exploitation in the food and pharmaceutical industries.

\section{RESULTS AND DISCUSSION}

2.1. Estimation of Phenolic Compounds in Bell Peppers (TPC, TFC, and TTC). TPC, TFC, and TTC assays were utilized to evaluate the phenolic content of different portions of Australian bell peppers. The result is displayed in Table 1, and the TPC of red bell capsicum pulp was significantly higher than that of other samples $(1.03 \pm 0.07$ $\mathrm{mg}$ GAE $/ \mathrm{g}_{\text {fresh weight (f.w.), }} p<0.05$ ) followed by yellow bell pepper pulp and red bell pepper seed $(0.72 \pm 0.06 \mathrm{mg}$ GAE/ $\mathrm{g}_{\text {f.w. }}$ and $0.53 \pm 0.03 \mathrm{mg} \mathrm{GAE} / \mathrm{g}_{\text {f.w. }}$, respectively). A previous study by Park et al. ${ }^{21}$ also indicated that red capsicums obtained a higher content of polyphenols than other colors of bell capsicums, while the TPC of red bell pulp in our research is less than that of red sweet peppers grown in Kunming, China (from 2 to $5 \mathrm{mg} \mathrm{GAE} / \mathrm{g}_{\text {f.w. }}$ ). ${ }^{22}$ This variation may be related to the accumulation of the ascorbic acid in capsicums, ${ }^{23}$ which can also react with Folin-Ciocalteau reagent and may cause an overestimation of TPC values. ${ }^{24}$

Flavonoids were found rich in various vegetables and play an important role in daily diets. ${ }^{25}$ Among all the pulp parts, red bell peppers had the highest value of TFC of $137.43 \pm 6.35 \mu \mathrm{g}$ $\mathrm{QE} / \mathrm{g}_{\text {f.w. }}(p<0.05)$, while the TFC of yellow pulp and green pulp had no significant difference. In terms of the seed portions, three bell peppers exhibited a range from 0.54 to 4.98 $\mu \mathrm{g} \mathrm{QE} / \mathrm{g}_{\text {f.w. }}$. Previous research by Sun et al. ${ }^{26}$ noticed that red peppers showed a significantly higher flavonoid content than green peppers, which was in agreement with our research. Flavonoid is a kind of pigment to prevent damage from sunlight, which will increase with the exposure time to UV radiation according to Mahdavian et al. ${ }^{27}$ Regarding the TTC assay, the red pulp contained the highest content of tannins $\left(0.22 \pm 0.01 \mathrm{mg} \mathrm{CE} / \mathrm{g}_{\text {f.w. }}\right)$, which is comparable with the previous study. ${ }^{28}$

2.2. Antioxidant Capacity of Bell Peppers (DPPH, ABTS, FRAP, and TAC). DPPH, ABTS, FRAP, and TAC assays were four common assays that were used to determine the antioxidant potential of samples through different mechanisms. The results were expressed as milligram ascorbic acid equivalents per gram in fresh weight $\left(\mathrm{mg} \mathrm{AAE} / \mathrm{g}_{\text {f.w. }}\right)$ in Table 1.

The TAC varied dramatically among the three types of bell peppers in this research. The pulp of red bell peppers exhibited the highest antioxidant capacity of $3.56 \pm 0.01 \mathrm{mg} \mathrm{AAE} / \mathrm{g}_{\text {f.w. }}$, followed by yellow and green pulps $\left(2.46 \pm 0.03 \mathrm{mg} \mathrm{AAE} / \mathrm{g}_{\text {f.w. }}\right.$. and $1.43 \pm 0.08 \mathrm{mg} \mathrm{AAE} / \mathrm{g}_{\text {f.w. }}$, respectively). The variation might be explained by the fact that the capsicums were harvested at different ripening stages. The antioxidant activity would be enhanced with the fruit ripening stage because of the accumulation of phytochemicals such as phenolic compounds, ascorbic acid, and carotenoids in the flesh part. ${ }^{26,29}$ All of these 
Table 2. Correlation Table of Phytochemical and Antioxidant Assays in Different Capsicum Fruits ${ }^{a}$

\begin{tabular}{|c|c|c|c|c|c|c|}
\hline & TPC & TFC & TTC & DPPH & FRAP & ABTS \\
\hline TFC & $0.841^{*}$ & & & & & \\
\hline TTC & 0.747 & 0.736 & & & & \\
\hline $\mathrm{DPPH}$ & $0.920 * *$ & 0.746 & 0.448 & & & \\
\hline FRAP & $0.984^{* *}$ & $0.846^{*}$ & 0.637 & $0.958^{* *}$ & & \\
\hline ABTS & $0.972 * *$ & $0.820^{*}$ & 0.617 & $0.976^{* *}$ & $0.985^{* *}$ & \\
\hline TAC & $0.898^{*}$ & $0.866^{*}$ & 0.479 & $0.965^{* *}$ & $0.950^{* *}$ & $0.958^{* *}$ \\
\hline
\end{tabular}

$a_{*}$ Indicates that the correlation between two assays is significantly correlated $(p<0.05)$; **indicates that the correlation between two assays is highly correlated $(p<0.01)$; total phenolic content: TPC, total flavonoid content: TFC, total tannin content: TTC, total antioxidant content: TAC, 2,2-diphenyl-1-picrylhydrazyl: DPPH, 2,2-azinobis-(3-ethylbenzo-thiazoline-6-sulfonic) acid: ABTS and ferric reducing antioxidant power: FRAP.

accumulated phytochemicals would contribute to the antioxidant activity of the bell peppers. ${ }^{30}$

According to Table 1, the highest DPPH activity among all the samples was found in the red pepper pulp $(0.89 \pm 0.01 \mathrm{mg}$ $\left.\mathrm{AAE} / \mathrm{g}_{\text {f.w. }}\right)$, followed by yellow pepper pulp $(0.75 \pm 0.04 \mathrm{mg}$ $\left.\mathrm{AAE} / \mathrm{g}_{\text {f.w. }}\right)$, while the other portions did not show a significant difference with a range from 0.11 to $0.17 \mathrm{mg} \mathrm{AAE} / \mathrm{g}_{\text {f.w. }}$. Meanwhile, the result of ABTS exhibited a similar trend. In the ABTS assay, red pulp accounted for the highest free radical scavenging capacity $\left(1.36 \pm 0.12 \mathrm{mg} \mathrm{AAE} / \mathrm{g}_{\text {f.w. }}\right)$. Our findings were supported by previous studies, which reported the green bell peppers to have a lower free radical scavenging ability than dark-color peppers such as yellow or red bell peppers. ${ }^{16,21}$ This variation might be involved in the fact that nutrients are continuously accumulated with mature stages. ${ }^{31}$

FRAP is generally used to determine the metal ion-chelating ability of the food matrix. ${ }^{32}$ The highest value of FRAP was found in the pulp of red bell capsicums $(0.15 \pm 0.01 \mathrm{mg}$ AAE/ $\mathrm{g}_{\text {f.w. }}$ ), which might be explained by the theory that the metal ion-chelating ability would increase with the maturating stage of peppers as described by $\mathrm{Sim}$ and $\mathrm{Sil}^{33}$ In short, phenolic and antioxidant properties differ among species and cultivars of the same plants grown in different regions under different climatic conditions, soil characteristics, and cultivation techniques. Moreover, the efficiency of the extraction of phenolics also varies under different extraction conditions, such as the type of solvents, solvent concentration, extraction time, temperature, solvent-to-solid ratio, and so on. ${ }^{34}$

2.3. Correlation of Phenolic Content and Antioxidant Assays. Pearson's correlations between the specific phenolic content (TPC, TFC, and TTC) and antioxidant assays (DPPH, ABTS, FRAP, and TAC) were performed to reveal the relationships between the phenolic content and antioxidant assays. The correlation coefficients are listed in Table 2, and the TPCs of bell peppers were positively correlated with all other assays except TTC (TFC, $r=0.841, p<0.05$; DPPH, $r=$ 0.920, $p<0.01$; FRAP, $r=0.984, p<0.01$; ABTS, $r=0.972, p$ $<0.01$; TAC, $r=0.898, p<0.05)$. In the previous study by Parikh and Patel, ${ }^{35}$ the TPC and TFC also exhibited a significant positive correlation in the food matrix $(r=0.8977$ and $p<0.05$ ), while the positive relationships between TPC and DPPH, as well as TPC and ABTS, were also reported by Cortés-Estrada et al. ${ }^{14}$ and Alvarez-Parrilla et al. ${ }^{36}$ The positive correlation among the TPC and antioxidant assays indicated that the phenolic compounds were the main contributors to the antioxidant capacity of all bell peppers. The positive correlations were also found between total flavonoids with FRAP, ABTS, and TAC $(r=0.8462, p<0.05 ; r=0.8201, p<$ $0.05 ; r=0.8655, p<0.05$, respectively), revealing that the flavonoid compound was one of the primary contributors to the antioxidant capacities. The phenolic contents in bell peppers exhibited remarkable antioxidant potentials; therefore, it is necessary to characterize the individual polyphenol for a more comprehensive understanding of the phenolic composition.

2.4. LC-ESI-QTOF-MS/MS Characterization of the Phenolic Compounds. Liquid chromatography-mass spectrometry (LC-MS) is a typical method used to identify phytochemicals in fruits and vegetables. In our research, untargeted qualitative analysis of individual phenolic compounds from bell peppers was conducted in both positive and negative ionization modes separately (Supporting Information) followed by the putative identification and characterization approach. ${ }^{37}$ Table 3 shows the putative identifications of the phenolic compounds that were tentatively identified based on their theoretical $\mathrm{m} / z$ values and isotope distributions (confirmation of the formulas) and MS/MS spectra (tentative confirmation of the structures) using Agilent MassHunter qualitative software and Personal Compound Database and Library (PCDL). Compounds with mass error $< \pm 5 \mathrm{ppm}$ were selected for further MS/MS identification and characterization purposes. In total, 59 compounds were tentatively isolated from all these three bell peppers, including phenolic acid (20), flavonoids (21), other polyphenols (12), and lignans (6).

2.4.1. Phenolic Acid. Phenolic acids have been identified as vital phenolic compounds in bell peppers. ${ }^{14}$ In this research, four subgroups of phenolic acids were identified in bell peppers, including hydroxybenzoic acids, hydroxycinnamic acids, hydroxyphenylpentanoic acids, and hydroxyphenylacetic acids.

2.4.1.1. Hydroxybenzoic and Hydroxyphenylpentanoic Acid Derivatives. Compound 1 was found in the seed and pulp of yellow peppers in both positive and negative modes with observed $[\mathrm{M}-\mathrm{H}]^{-} \mathrm{m} / z$ at $331.0674, \mathrm{RT}=6.866$. According to the fragmentations, compound 1 suffered a neutral loss of $162 \mathrm{Da}$ and a further loss of $\mathrm{CO}_{2}$ molecules (42 $\mathrm{Da})$, resulting in the product ion at $\mathrm{m} / z 169$ and $\mathrm{m} / z 125$, respectively. These two fragments were reported to be the identical loss of galloyl glucose, ${ }^{38}$ which was previously characterized from berries, such as blackcurrants, instead of capsicum sp. ${ }^{39}$ Compound 2 with $[\mathrm{M}+\mathrm{H}]^{+} \mathrm{m} / z$ at 185.0444 was only detected in the seed of green bell pepper and characterized as 4-O-methylgallic acid according to the product ion at 170 and $142 \mathrm{~m} / z$, corresponding to the loss of $\mathrm{CH}_{3}(15$ $\mathrm{Da})$ and $\left(\mathrm{CH}_{3}+\mathrm{CO}\right)(43 \mathrm{Da})$, respectively. ${ }^{40}$ Gallic acid and its derivatives 4-O-methylgallic acid are reported to be the main hydroxybenzoic compounds isolated from bell peppers with remarkable antioxidant capacity. ${ }^{11}$ 2-Hydroxybenzoic acid (compound 3 at $[\mathrm{M}-\mathrm{H}]^{-} \mathrm{m} / z$ 137.0247) was discovered in the seeds of red and yellow bell peppers. The identity was 
Table 3. Characterization of Phenolic Compounds in Bell Peppers Using LC-ESI-QTOF-MS/MS

\begin{tabular}{|c|c|c|c|c|c|c|c|c|c|c|}
\hline no. & proposed compounds & $\begin{array}{l}\text { molecular } \\
\text { formula }\end{array}$ & $\begin{array}{l}\mathrm{RT} \\
(\mathrm{min})\end{array}$ & $\begin{array}{c}\text { ionization } \\
\left(\mathrm{ESI}^{+} / \mathrm{ESI}^{-}\right)\end{array}$ & $\begin{array}{l}\text { molecular } \\
\text { weight }\end{array}$ & $\begin{array}{l}\text { theoretical } \\
\qquad(m / z)\end{array}$ & $\begin{array}{l}\text { observed } \\
(m / z)\end{array}$ & $\begin{array}{l}\text { mass error } \\
(\mathrm{ppm})\end{array}$ & $\begin{array}{l}\text { MS/MS } \\
\text { product ions }\end{array}$ & $\begin{array}{l}\text { bell pepper } \\
\text { samples }\end{array}$ \\
\hline \multicolumn{11}{|c|}{ phenolic acid } \\
\hline \multicolumn{11}{|c|}{ hydroxybenzoic acids } \\
\hline 1 & galloyl glucose & $\mathrm{C}_{13} \mathrm{H}_{16} \mathrm{O}_{10}$ & 6.866 & {$[\mathrm{M}-\mathrm{H}]^{-b}$} & 332.0743 & 331.067 & 331.0674 & 1.2 & 169,125 & $\mathrm{YCS}, \mathrm{YCP}^{a}$ \\
\hline 2 & 4-O-methylgallic acid & $\mathrm{C}_{8} \mathrm{H}_{8} \mathrm{O}_{5}$ & 12.938 & {$[\mathrm{M}+\mathrm{H}]^{+}$} & 184.0372 & 185.0445 & 185.0444 & -0.5 & 170,142 & GCS \\
\hline 3 & 2-hydroxybenzoic acid & $\mathrm{C}_{7} \mathrm{H}_{6} \mathrm{O}_{3}$ & 23.646 & {$[\mathrm{M}-\mathrm{H}]^{-}$} & 138.0317 & 137.0244 & 137.0247 & 2.2 & 93 & $\mathrm{YCS}, \mathrm{RCS}^{a}$ \\
\hline \multicolumn{11}{|c|}{ hydroxycinnamic acids } \\
\hline 4 & caffeic acid & $\mathrm{C}_{9} \mathrm{H}_{8} \mathrm{O}_{4}$ & 4.575 & {$[\mathrm{M}-\mathrm{H}]^{-}$} & 180.0423 & 179.035 & 179.0353 & 1.7 & $\begin{array}{l}151,143 \\
133\end{array}$ & RCS \\
\hline 5 & $p$-coumaroyl malic acid & $\mathrm{C}_{13} \mathrm{H}_{12} \mathrm{O}_{7}$ & 5.953 & {$[\mathrm{M}-\mathrm{H}]^{-b}$} & 280.0583 & 279.051 & 279.0514 & 1.4 & 163 & GCS, YCS, RCS ${ }^{a}$ \\
\hline 6 & $1,2,2^{\prime}$-triferuloylgentiobiose & $\mathrm{C}_{42} \mathrm{H}_{46} \mathrm{O}_{20}$ & 9.548 & {$[\mathrm{M}-\mathrm{H}]^{-}$} & 870.2582 & 869.2509 & 869.2533 & 2.8 & 693,517 & YCS \\
\hline 7 & caffeic acid 3-O-glucuronide & $\mathrm{C}_{15} \mathrm{H}_{16} \mathrm{O}_{10}$ & 12.082 & {$[\mathrm{M}-\mathrm{H}]^{-b}$} & 356.0743 & 355.0670 & 355.0659 & -3.1 & 179 & $\mathrm{YCP}, \mathrm{RCP}^{a}$ \\
\hline 8 & cinnamic acid & $\mathrm{C}_{9} \mathrm{H}_{8} \mathrm{O}_{2}$ & 12.430 & {$[\mathrm{M}+\mathrm{H}]^{-b}$} & 148.0524 & 149.0597 & 149.0603 & 4.0 & 103 & $\begin{array}{l}\text { YCP, GCP, RCP, } \\
\text { YCS, RCS }\end{array}$ \\
\hline 9 & caffeoyl glucose & $\mathrm{C}_{15} \mathrm{H}_{18} \mathrm{O}_{9}$ & 18.809 & {$[\mathrm{M}-\mathrm{H}]^{-}$} & 342.0951 & 341.0878 & 341.0892 & 4.1 & 179,161 & GCS, YCS, RCS ${ }^{a}$ \\
\hline 10 & 3-feruloylquinic acid & $\mathrm{C}_{17} \mathrm{H}_{20} \mathrm{O}_{9}$ & 20.847 & {$[\mathrm{M}-\mathrm{H}]^{-b}$} & 368.1107 & 367.1034 & 367.1025 & -2.5 & $\begin{array}{l}298,288 \\
192,191\end{array}$ & $\begin{array}{l}\text { GCS, YCS, RCS, } \\
\text { RCP, YCP }\end{array}$ \\
\hline 11 & 3-caffeoylquinic acid & $\mathrm{C}_{16} \mathrm{H}_{18} \mathrm{O}_{9}$ & 24.757 & {$[\mathrm{M}-\mathrm{H}]^{-}$} & 354.0951 & 353.0878 & 353.0891 & 3.7 & $\begin{array}{l}253,190 \\
144\end{array}$ & GCS, $\mathrm{YCS}^{a}$ \\
\hline 12 & ferulic acid 4-O-glucoside & $\mathrm{C}_{16} \mathrm{H}_{20} \mathrm{O}_{9}$ & 29.312 & {$[\mathrm{M}-\mathrm{H}]^{-}$} & 356.1107 & 355.1034 & 355.1043 & 2.5 & $\begin{array}{l}193,178 \\
149,134\end{array}$ & $\mathrm{GCS}, \mathrm{YCS}, \mathrm{GCP}^{a}$ \\
\hline 13 & 1,5-dicaffeoylquinic acid & $\mathrm{C}_{25} \mathrm{H}_{24} \mathrm{O}_{12}$ & 31.035 & {$[\mathrm{M}-\mathrm{H}]^{-}$} & 516.1268 & 515.1195 & 515.1208 & 2.5 & $\begin{array}{l}353,335 \\
191,179\end{array}$ & GCS, $\mathrm{YCS}^{a}$ \\
\hline 14 & rosmarinic acid & $\mathrm{C}_{18} \mathrm{H}_{16} \mathrm{O}_{8}$ & 39.746 & {$[\mathrm{M}-\mathrm{H}]^{-b}$} & 360.0845 & 359.0772 & 359.0773 & 0.3 & 179 & GCS \\
\hline 15 & isoferulic acid & $\mathrm{C}_{10} \mathrm{H}_{10} \mathrm{O}_{4}$ & 42.847 & {$[\mathrm{M}-\mathrm{H}]^{-b}$} & 194.0579 & 193.0506 & 193.0506 & 0.0 & $\begin{array}{l}178,149 \\
134\end{array}$ & GCS, YCS, RCS ${ }^{a}$ \\
\hline 16 & cinnamoyl glucose & $\mathrm{C}_{15} \mathrm{H}_{18} \mathrm{O}_{7}$ & 60.985 & {$[\mathrm{M}-\mathrm{H}]^{-b}$} & 310.1053 & 309.0980 & 309.0965 & -4.9 & $\begin{array}{l}147,131 \\
103\end{array}$ & GCS \\
\hline \multicolumn{11}{|c|}{ hydroxyphenylacetic acids } \\
\hline 17 & 3,4-dihydroxyphenylacetic acid & $\mathrm{C}_{8} \mathrm{H}_{8} \mathrm{O}_{4}$ & 27.904 & {$[\mathrm{M}-\mathrm{H}]^{-b}$} & 168.0423 & 167.0350 & 167.0346 & -2.4 & 149,123 & $\begin{array}{l}\text { GCS, YCS, RCS, } \\
\mathrm{GCP}^{a}\end{array}$ \\
\hline 18 & 2-hydroxy-2-phenylacetic acid & $\mathrm{C}_{8} \mathrm{H}_{8} \mathrm{O}_{3}$ & 36.105 & {$[\mathrm{M}-\mathrm{H}]^{-}$} & 152.0473 & 151.0400 & 151.0407 & 4.6 & 136,92 & GCS \\
\hline \multicolumn{11}{|c|}{ hydroxyphenylpentanoic acids } \\
\hline 19 & $\begin{array}{l}\text { 3-hydroxy-3-(3- } \\
\text { hydroxyphenyl) propionic } \\
\text { acid }\end{array}$ & $\mathrm{C}_{9} \mathrm{H}_{10} \mathrm{O}_{4}$ & 12.842 & {$[\mathrm{M}-\mathrm{H}]^{-}$} & 182.0579 & 181.0506 & 181.0509 & 1.6 & $\begin{array}{l}163,135 \\
119\end{array}$ & RCS \\
\hline 20 & $\begin{array}{l}\text { dihydrocaffeic acid 3-O- } \\
\text { glucuronide }\end{array}$ & $\mathrm{C}_{15} \mathrm{H}_{18} \mathrm{O}_{10}$ & 20.796 & {$[\mathrm{M}-\mathrm{H}]^{-b}$} & 358.0900 & 357.0827 & 357.0828 & 0.3 & 181 & $\begin{array}{l}\mathrm{GCP}, \mathrm{YCP}, \mathrm{RCP} \\
\mathrm{GCS}^{a}\end{array}$ \\
\hline \multicolumn{11}{|c|}{ flavonoids } \\
\hline \multicolumn{11}{|c|}{ flavanols } \\
\hline 21 & (-)-epigallocatechin & $\mathrm{C}_{15} \mathrm{H}_{14} \mathrm{O}_{7}$ & 10.622 & {$[\mathrm{M}-\mathrm{H}]^{-b}$} & 306.0740 & 305.0667 & 305.0659 & -2.6 & 261,219 & $\begin{array}{l}\text { YCP, YCS, RCS, } \\
\mathrm{RCP}^{a}\end{array}$ \\
\hline 22 & $\begin{array}{l}\text { 4"-O-methylepigallocatechin } \\
\text { 3-O-gallate }\end{array}$ & $\mathrm{C}_{23} \mathrm{H}_{20} \mathrm{O}_{11}$ & 11.410 & {$[\mathrm{M}-\mathrm{H}]^{-}$} & 472.1006 & 471.0933 & 471.0950 & 4.0 & 319,169 & YCS \\
\hline 23 & $(+)$-catechin 3-O-gallate & $\mathrm{C}_{22} \mathrm{H}_{18} \mathrm{O}_{10}$ & 22.306 & {$[\mathrm{M}-\mathrm{H}]^{-b}$} & 442.0900 & 441.0827 & 441.0805 & -5.0 & $\begin{array}{l}289,169 \\
125\end{array}$ & RCS \\
\hline 24 & $\begin{array}{l}\text { 4'-O-methyl- } \\
(-) \text {-epigallocatechin } 7-O- \\
\text { glucuronide }\end{array}$ & $\mathrm{C}_{22} \mathrm{H}_{24} \mathrm{O}_{13}$ & 25.999 & {$[\mathrm{M}-\mathrm{H}]^{-}$} & 496.1217 & 495.1144 & 495.1163 & 3.8 & 415,313 & YCS \\
\hline 25 & $(-)$-epicatechin & $\mathrm{C}_{15} \mathrm{H}_{14} \mathrm{O}_{6}$ & 31.118 & {$[\mathrm{M}-\mathrm{H}]^{-b}$} & 290.0790 & 289.0717 & 289.0717 & 0.0 & $\begin{array}{l}245,205 \\
179\end{array}$ & $\begin{array}{l}\mathrm{GCS}, \mathrm{YCS}, \mathrm{RCS} \\
\mathrm{YCP}^{a}\end{array}$ \\
\hline 26 & procyanidin trimer $\mathrm{C} 1$ & $\mathrm{C}_{45} \mathrm{H}_{38} \mathrm{O}_{18}$ & 33.736 & {$[\mathrm{M}-\mathrm{H}]^{-}$} & 866.2058 & 865.1985 & 865.1990 & 0.6 & $\begin{array}{l}739,713 \\
695\end{array}$ & YCS \\
\hline \multicolumn{11}{|c|}{ flavonols } \\
\hline 27 & $\begin{array}{l}\text { quercetin 3-O-glucosyl- } \\
\text { xyloside }\end{array}$ & $\mathrm{C}_{26} \mathrm{H}_{28} \mathrm{O}_{16}$ & 15.395 & {$[\mathrm{M}-\mathrm{H}]^{-b}$} & 596.1377 & 595.1304 & 595.1299 & -0.8 & $\begin{array}{l}265,138 \\
116\end{array}$ & $\mathrm{GCP}, \mathrm{YCP}, \mathrm{RCP}^{a}$ \\
\hline 28 & 3-methoxysinensetin & $\mathrm{C}_{21} \mathrm{H}_{22} \mathrm{O}_{8}$ & 16.528 & {$[\mathrm{M}+\mathrm{H}]^{+b}$} & 402.1315 & 403.1388 & 403.1395 & 1.7 & $\begin{array}{l}388,373 \\
355,327\end{array}$ & GCS \\
\hline 29 & myricetin 3-O-glucoside & $\mathrm{C}_{21} \mathrm{H}_{20} \mathrm{O}_{13}$ & 34.017 & {$[\mathrm{M}-\mathrm{H}]^{-b}$} & 480.0904 & 479.0831 & 479.0833 & 0.4 & 317 & $\mathrm{RCP}$ \\
\hline \multicolumn{11}{|c|}{ flavanones } \\
\hline 30 & naringin $4^{\prime}$-O-glucoside & $\mathrm{C}_{33} \mathrm{H}_{42} \mathrm{O}_{19}$ & 12.481 & {$[\mathrm{M}-\mathrm{H}]^{-}$} & 742.2320 & 741.2247 & 741.2273 & 3.5 & 433,271 & $\mathrm{GCS}, \mathrm{RCS}^{a}$ \\
\hline 31 & 7,4'-dihydroxyflavone & $\mathrm{C}_{15} \mathrm{H}_{10} \mathrm{O}_{4}$ & 13.972 & {$[\mathrm{M}+\mathrm{H}]^{+}$} & 254.0579 & 255.0652 & 255.0641 & -4.3 & $\begin{array}{l}227,199 \\
171\end{array}$ & YCS \\
\hline 32 & apigenin 7 -O-glucuronide & $\mathrm{C}_{21} \mathrm{H}_{18} \mathrm{O}_{11}$ & 15.812 & {$[\mathrm{M}+\mathrm{H}]^{+b}$} & 446.0849 & 447.0922 & 447.0930 & 1.8 & 271,253 & YCS \\
\hline $\begin{array}{l}33 \\
\text { isof }\end{array}$ & \multicolumn{9}{|c|}{ isoflavonoids } & $\mathrm{GCS}, \mathrm{RCS}, \mathrm{GCP}^{a}$ \\
\hline 34 & $6 "-O$-acetyldaidzin & $\mathrm{C}_{23} \mathrm{H}_{22} \mathrm{O}_{10}$ & 4.413 & {$[\mathrm{M}-\mathrm{H}]^{-b}$} & 458.1213 & 457.1140 & 457.1125 & -3.3 & 221 & $\mathrm{RCP}$ \\
\hline 35 & $6^{\prime \prime}-O$-acetylglycitin & $\mathrm{C}_{24} \mathrm{H}_{24} \mathrm{O}_{11}$ & 7.378 & {$[\mathrm{M}+\mathrm{H}]^{+}$} & 488.1319 & 489.1392 & 489.1387 & -1.0 & 285,270 & $\mathrm{YCP}, \mathrm{GCP}^{a}$ \\
\hline
\end{tabular}


Table 3. continued

\begin{tabular}{|c|c|c|c|c|c|c|c|c|c|c|}
\hline no. & proposed compounds & $\begin{array}{l}\text { molecular } \\
\text { formula }\end{array}$ & $\begin{array}{l}\mathrm{RT} \\
(\mathrm{min})\end{array}$ & $\begin{array}{l}\text { ionization } \\
\left(\mathrm{ESI}^{+} / \mathrm{ESI}^{-}\right)\end{array}$ & $\begin{array}{l}\text { molecular } \\
\text { weight }\end{array}$ & $\begin{array}{l}\text { theoretical } \\
\qquad(m / z)\end{array}$ & $\begin{array}{l}\text { observed } \\
(m / z)\end{array}$ & $\begin{array}{l}\text { mass error } \\
(\mathrm{ppm})\end{array}$ & $\begin{array}{l}\text { MS/MS } \\
\text { product ions }\end{array}$ & $\begin{array}{l}\text { bell pepper } \\
\text { samples }\end{array}$ \\
\hline 36 & $6^{\prime \prime}-O$-malonyldaidzin & $\mathrm{C}_{24} \mathrm{H}_{22} \mathrm{O}_{12}$ & 16.246 & {$[\mathrm{M}+\mathrm{H}]^{-b}$} & 502.1111 & 503.1184 & 503.1200 & 3.2 & 255 & YCS \\
\hline 37 & $3^{\prime}$-hydroxygenistein & $\mathrm{C}_{15} \mathrm{H}_{10} \mathrm{O}_{6}$ & 31.357 & {$[\mathrm{M}+\mathrm{H}]^{+}$} & 286.0477 & 287.0550 & 287.0540 & -3.5 & 269,259 & GCS \\
\hline 38 & $2^{\prime}$-hydroxyformononetin & $\mathrm{C}_{16} \mathrm{H}_{12} \mathrm{O}_{5}$ & 37.872 & {$[\mathrm{M}+\mathrm{H}]^{+}$} & 284.0685 & 285.0758 & 285.0767 & 3.2 & $\begin{array}{l}270,253 \\
229,225\end{array}$ & GCP \\
\hline 39 & formononetin 7-O-glucuronide & $\mathrm{C}_{22} \mathrm{H}_{20} \mathrm{O}_{10}$ & 41.953 & {$[\mathrm{M}-\mathrm{H}]^{-}$} & 444.1056 & 443.0983 & 443.0976 & -1.6 & 267,252 & YCS, GCS, $\mathrm{RCS}^{a}$ \\
\hline 40 & $\begin{array}{l}\text { 3-hydroxyphloretin } 2^{\prime} \text {-O- } \\
\text { glucoside }\end{array}$ & $\mathrm{C}_{21} \mathrm{H}_{24} \mathrm{O}_{11}$ & 42.383 & {$[\mathrm{M}-\mathrm{H}]^{-}$} & 452.1319 & 451.1246 & 451.1237 & -2.0 & 289,273 & $\mathrm{GCS}, \mathrm{RCS}^{a}$ \\
\hline 41 & $\begin{array}{l}\text { dihydromyricetin 3-O- } \\
\text { rhamnoside }\end{array}$ & $\mathrm{C}_{21} \mathrm{H}_{22} \mathrm{O}_{12}$ & 45.349 & {$[\mathrm{M}-\mathrm{H}]^{-}$} & 466.1111 & 465.1038 & 465.1036 & -0.4 & 301 & GCS \\
\hline \multicolumn{11}{|c|}{ other polyphenols } \\
\hline \multicolumn{11}{|c|}{ hydroxybenzaldehydes } \\
\hline 42 & $p$-anisaldehyde & $\mathrm{C}_{8} \mathrm{H}_{8} \mathrm{O}_{2}$ & 29.312 & {$[\mathrm{M}+\mathrm{H}]^{+b}$} & 136.0524 & 135.0451 & 135.0452 & 0.7 & 122,109 & $\begin{array}{l}\text { YCS, RCP, GCP, } \\
\text { YCP }^{a}\end{array}$ \\
\hline \multicolumn{11}{|c|}{ curcuminoids } \\
\hline 43 & Demethoxycurcumin & $\mathrm{C}_{20} \mathrm{H}_{18} \mathrm{O}_{5}$ & 76.809 & {$[\mathrm{M}-\mathrm{H}]^{-}$} & 338.1154 & 337.1081 & 337.1087 & 1.8 & 217 & $\mathrm{RCS}, \mathrm{GCS}^{a}$ \\
\hline \multicolumn{11}{|c|}{ furanocoumarins } \\
\hline 44 & isopimpinellin & $\mathrm{C}_{13} \mathrm{H}_{10} \mathrm{O}_{5}$ & 4.478 & {$[\mathrm{M}+\mathrm{H}]^{+b}$} & 246.0528 & 247.0601 & 247.0605 & 1.6 & $\begin{array}{l}232,217 \\
205,203\end{array}$ & RCS \\
\hline 45 & $\begin{array}{l}\text { 2,3-dihydroxy-1- } \\
\text { guaiacylpropanone }\end{array}$ & $\mathrm{C}_{10} \mathrm{H}_{12} \mathrm{O}_{5}$ & 9.879 & {$[\mathrm{M}-\mathrm{H}]^{-b}$} & 212.0685 & 211.0612 & 211.0602 & -4.7 & $\begin{array}{r}167,123 \\
105,93\end{array}$ & YCS \\
\hline 46 & $\begin{array}{l}\text { 2-hydroxy-4- } \\
\text { methoxyacetophenone 5- } \\
\text { sulfate }\end{array}$ & $\mathrm{C}_{9} \mathrm{H}_{10} \mathrm{O}_{7} \mathrm{~S}$ & 12.891 & {$[\mathrm{M}-\mathrm{H}]^{-}$} & 262.0147 & 261.0074 & 261.0078 & 1.5 & 181,97 & RCS \\
\hline 47 & coumarin & $\mathrm{C}_{9} \mathrm{H}_{6} \mathrm{O}_{2}$ & 15.875 & {$[\mathrm{M}+\mathrm{H}]^{+}$} & 146.0368 & 147.0441 & 147.0447 & 4.1 & 103,91 & YCP \\
\hline 48 & esculin & $\mathrm{C}_{15} \mathrm{H}_{16} \mathrm{O}_{9}$ & 82.047 & {$[\mathrm{M}+\mathrm{H}]^{+}$} & 340.0794 & 341.0867 & 341.087 & 0.9 & 179,151 & $\mathrm{GCP}, \mathrm{RCP}^{a}$ \\
\hline \multicolumn{11}{|c|}{ tyrosols } \\
\hline 49 & 3,4-DHPEA-AC & $\mathrm{C}_{10} \mathrm{H}_{12} \mathrm{O}_{4}$ & 9.515 & {$[\mathrm{M}-\mathrm{H}]^{-}$} & 196.0736 & 195.0663 & 195.0667 & 2.1 & 135 & $\mathrm{GCS}, \mathrm{RCS}^{a}$ \\
\hline 50 & demethyloleuropein & $\mathrm{C}_{24} \mathrm{H}_{30} \mathrm{O}_{13}$ & 23.100 & {$[\mathrm{M}-\mathrm{H}]^{-}$} & 526.1686 & 525.1613 & 525.1621 & 1.5 & 495 & $\mathrm{GCS}, \mathrm{YCS}^{a}$ \\
\hline 51 & 3,4-DHPEA-EDA & $\mathrm{C}_{17} \mathrm{H}_{20} \mathrm{O}_{6}$ & 23.564 & {$[\mathrm{M}-\mathrm{H}]^{-}$} & 320.1260 & 319.1187 & 319.1189 & 0.6 & 275,195 & $\mathrm{YCS}, \mathrm{RCS}^{a}$ \\
\hline 52 & hydroxytyrosol 4-O-glucoside & $\mathrm{C}_{14} \mathrm{H}_{20} \mathrm{O}_{8}$ & 43.474 & {$[\mathrm{M}-\mathrm{H}]^{-}$} & 316.1158 & 315.1085 & 315.1072 & -4.1 & 153,123 & $\mathrm{RCS}$ \\
\hline 53 & lithospermic acid & $\mathrm{C}_{27} \mathrm{H}_{22} \mathrm{O}_{12}$ & 31.035 & {$[\mathrm{M}-\mathrm{H}]^{-}$} & 538.1111 & 537.1038 & 537.1047 & 1.7 & $\begin{array}{l}493,339 \\
295\end{array}$ & GCS, $\mathrm{YCS}^{a}$ \\
\hline \multicolumn{11}{|c|}{ lignans } \\
\hline \multicolumn{11}{|c|}{ lignans } \\
\hline 54 & enterolactone & $\mathrm{C}_{18} \mathrm{H}_{18} \mathrm{O}_{4}$ & 4.234 & {$[\mathrm{M}+\mathrm{H}]^{+b}$} & 298.1205 & 299.1278 & 299.1279 & 0.3 & $\begin{array}{l}281,187 \\
165\end{array}$ & GCS \\
\hline 55 & schisanhenol & $\mathrm{C}_{23} \mathrm{H}_{30} \mathrm{O}_{6}$ & 22.684 & {$[\mathrm{M}+\mathrm{H}]^{+}$} & 402.2042 & 403.2115 & 403.2100 & -3.7 & $\begin{array}{l}385,354 \\
331\end{array}$ & $\mathrm{GCP}^{a}$ \\
\hline 56 & schisandrin C & $\mathrm{C}_{22} \mathrm{H}_{24} \mathrm{O}_{6}$ & 32.682 & {$[\mathrm{M}+\mathrm{H}]^{+b}$} & 384.1573 & 385.1646 & 385.1651 & 1.3 & $\begin{array}{l}370,315 \\
300\end{array}$ & GCS, $\mathrm{RCS}^{a}$ \\
\hline 57 & todolactol A & $\mathrm{C}_{20} \mathrm{H}_{24} \mathrm{O}_{7}$ & 41.489 & {$[\mathrm{M}-\mathrm{H}]^{+b}$} & 376.1522 & 375.1449 & 375.1438 & 3.4 & 313,137 & $\begin{array}{l}\mathrm{GCS}, \mathrm{YCS}, \mathrm{RCS} \\
\mathrm{RCP}^{a}\end{array}$ \\
\hline 58 & matairesinol & $\mathrm{C}_{20} \mathrm{H}_{22} \mathrm{O}_{6}$ & 61.187 & {$[\mathrm{M}-\mathrm{H}]^{-}$} & 358.1416 & 357.1343 & 357.1337 & -1.7 & $\begin{array}{l}342,327 \\
313,221\end{array}$ & YCS \\
\hline
\end{tabular}

stilbenes

stilbenes

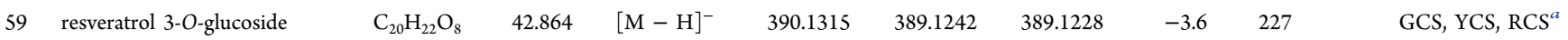

${ }^{a}$ Compound was detected in more than one bell pepper samples, and data presented in this table are from the asterisk sample. ${ }^{b}$ Compounds were detected in both negative $[\mathrm{M}-\mathrm{H}]^{-}$and positive $[\mathrm{M}+\mathrm{H}]^{+}$modes of ionization while only single-mode data were presented.

confirmed by its product ion at $m / z$ 93, corresponding to the loss of $\mathrm{CO}_{2}(44 \mathrm{Da}){ }^{41}$ 2-Hydroxybenzoic acid is a kind of phenolic compound abundant in fruits, vegetables, and herbs. ${ }^{42}$ To the best of our knowledge, this is the first time that the presence of 2-hydroxybenzoic acid in bell peppers is reported.

Compound 19 is a derivative of hydroxyphenylpentanoic acids putatively characterized in the $\mathrm{ESI}^{-}$mode with observed $\mathrm{m} / z$ at 181.0509 in the seed of red bell peppers. The distinctive fragments were observed at $\mathrm{m} / z 163,135$, and 119 which are related to the loss of $\mathrm{H}_{2} \mathrm{O}, \mathrm{HCOOH}$, and $\mathrm{H}_{2} \mathrm{O}$ plus $\mathrm{CO}_{2}$, respectively. ${ }^{43}$ 3-Hydroxy-3-(3-hydroxyphenyl) propionic acid has been captured from the hops and juniper berry, $^{44}$ while this is the first time to characterize it from capsicum spp.
2.4.1.2. Hydroxycinnamic Acid Derivatives. Hydroxycinnamic acids exist in foods in either free form or bound to other polymers, $^{45}$ and a total of 13 hydroxycinnamic acids were tentatively characterized in the extracts of bell peppers. Caffeic acid (compound 4) with $[\mathrm{M}-\mathrm{H}]^{-} \mathrm{m} / z$ at 179.0353 was identified from the seed of red bell peppers, and the product ions were noticed at 151,143 , and 133 , because of the loss of $\mathrm{CO}(28 \mathrm{Da})$, two $\mathrm{H}_{2} \mathrm{O}(36 \mathrm{Da})$ molecules, and $\mathrm{HCOOH}(46$ $\mathrm{Da})$, respectively. ${ }^{46}$ Caffeic acid has been successfully isolated from various fruits and vegetables, such as bell peppers, apple, kiwi fruits, pear, and guava with remarkable antioxidant potential through HPLC experiments. ${ }^{17,45,47,48}$

The precursor of 1,2,2'-triferuloylgentiobiose (compound 6) was at $[\mathrm{M}-\mathrm{H}]^{-} \mathrm{m} / z 869.2533$, providing fragment ions at $m$ / $z 693\left(\mathrm{C}_{32} \mathrm{H}_{38} \mathrm{O}_{17}\right)$ and $m / z 517\left(\mathrm{C}_{22} \mathrm{H}_{30} \mathrm{O}_{14}\right)$, corresponding 
to the loss of one feruloyl unit $\left(\mathrm{C}_{10} \mathrm{H}_{8} \mathrm{O}_{3}\right)$ and two feruloyl units, respectively. ${ }^{49} 1,2,2^{\prime}$-Triferuloylgentiobiose is a derivative of ferulic acid which has been identified in broccoli cultivars. ${ }^{50}$ To the best of our knowledge, this is the first time that $1,2,2^{\prime}$-triferuloylgentiobiose is discovered in bell peppers.

Compounds 5, 9, and 15 were three hydroxycinnamic acids only isolated from seeds of bell peppers. Compound $\mathbf{5}$ detected in both modes with observed $[\mathrm{M}-\mathrm{H}]^{-} \mathrm{m} / z$ at 279.0514 was inferred as $p$-coumaroyl malic acid according to the fragment at $m / z 163$, corresponding to the loss of malic acid $\left(\mathrm{C}_{4} \mathrm{H}_{4} \mathrm{O}_{4}\right)$, and it was previously identified in the powder of tomatoes. ${ }^{51,52}$ Caffeoyl glucose (compound 9) was characterized in the negative mode at $m / z$ 341.0892, in which the $\mathrm{MS}^{2}$ spectrum showed the product ions at $m / z 179$ and $m / z \quad 161$, corresponding to the loss of the hexosyl moiety and further loss of a water molecule. ${ }^{53}$ Caffeoyl glucose has been isolated from black currents, tomatoes, eggplants, chili peppers, and bell peppers with superb antioxidant potentials. ${ }^{45}$ Compound 15 was tentatively identified as isoferulic acid $\left([\mathrm{M}-\mathrm{H}]^{-} \mathrm{m} / z\right.$ at 193.0506) because of the loss of $\mathrm{CH}_{3}, \mathrm{CO}_{2}$, and $\left(\mathrm{CH}_{3}+\right.$ $\mathrm{CO}_{2}$ ), resulting in the major fragment ions at $\mathrm{m} / z 178, \mathrm{~m} / z$ 149 , and $m / z 134$, respectively. ${ }^{43}$ The identification of ferulic acid 4-O-glucoside (compound 12 with $\mathrm{m} / z 355.1043$ in the $\mathrm{ESI}^{-}$mode) was achieved by the product ions at $\mathrm{m} / z 193, \mathrm{~m} / z$ $178, m / z 149$, and $m / z 134$, which arose from the loss of $\mathrm{C}_{6} \mathrm{H}_{10} \mathrm{O}_{5}(162 \mathrm{Da}), \mathrm{C}_{7} \mathrm{H}_{13} \mathrm{O}_{5}(177), \mathrm{C}_{7} \mathrm{H}_{10} \mathrm{O}_{7}(206 \mathrm{Da})$, and $\mathrm{C}_{8} \mathrm{H}_{13} \mathrm{O}_{7} \quad(221 \mathrm{Da})$ from the parent ion, respectively. ${ }^{54}$ Isoferulic acid is generally isolated from Chinese propolis that play an important role in scavenging free radicals and was also reported in bell peppers in a previous study. ${ }^{55,56}$

Compounds 11 and 13 were two compounds captured in the seeds of green and yellow bell peppers. 3-Caffeoylquinic acid (compound 11) was detected in the negative mode with observed $\mathrm{m} / \mathrm{z}$ at 353.0891, and the fragmentation resulted in the product ions at $m / z 253\left[\mathrm{M}-\mathrm{H}-3 \mathrm{H}_{2} \mathrm{O}-\mathrm{HCOOH}\right]^{-}, m /$ $z 190\left[\mathrm{M}-\mathrm{H}-3 \mathrm{H}_{2} \mathrm{O}-\mathrm{C}_{6} \mathrm{H}_{5} \mathrm{O}_{2}\right]^{-}$, and $m / z 144[\mathrm{M}-\mathrm{H}-$ $\left.\mathrm{H}_{2} \mathrm{O}-\mathrm{C}_{7} \mathrm{H}_{11} \mathrm{O}_{6}\right]^{-}$. ${ }^{46}$ 1,5-Dicaffeoylquinic acid was proposed as compound 13, showing the parent ion at $m / z 515.1208$ in the $\mathrm{ESI}^{-}$mode. The MS ${ }^{2}$ spectrum showed the product ions at $m$ / $z 353,335$, and $m / z 191$, indicating the possible loss of $\mathrm{C}_{9} \mathrm{H}_{6} \mathrm{O}_{3}(162 \mathrm{Da}), \mathrm{C}_{9} \mathrm{H}_{8} \mathrm{O}_{4}(180 \mathrm{Da})$, and $\mathrm{C}_{18} \mathrm{H}_{12} \mathrm{O}_{6}(324 \mathrm{Da})$ from the parent ion, respectively. ${ }^{53}$ Caffeoylquinic acids have been identified in the leaves of red peppers (capsicum spp.) as well as Chrysanthemum coronarium L. (as known as Tonghao, a kind of edible vegetable) with health-promoting properties. $^{57,58}$ Cinnamic acid (compound 8) was detected in all samples except the seed of green bell peppers, which was found in both $\mathrm{ESI}^{+}$and $\mathrm{ESI}^{-}$modes. In the current study, compound 8 with precursor $m / z$ at 149.0603 was expressed in the positive mode of the pulp of red bell peppers, and the typical product ion was at $m / z 103$, corresponding to the loss of a carboxylic acid moiety unit $(46 \mathrm{Da}) .{ }^{54}$ Cinnamic acid and its derivatives are normally present in fruits and vegetables, including citrus fruits, grape, tea, cocoa, spinach, and celery, ${ }^{56}$ while this is the first time that cinnamic acid is reported in bell peppers.

2.4.2. Flavonoids. 2.4.2.1. Flavanols and Flavanone Derivatives. Compounds 22 and 26 were only observed in the seed of yellow peppers in the negative mode with the precursor at $m / z 473.1098$ and $m / z$ 865.1990, respectively. Compound 22 was tentatively inferred as 4 "-O-methylepigallocatechin 3-O-gallate by comparing the characteristic fragment ions at $\mathrm{m} / z 319$ and $\mathrm{m} / z 169$, indicating the presence of the galloyl group and methyl-(epi)gallocatechin. ${ }^{59}$ Galloylated catechins have stronger scavenging properties than nongalloylated catechins, and the (-)-epigallocatechin gallate is considered to have the highest ability to prohibit free radicals, which was the first time to be reported in peppers. ${ }^{60,61}$ The identity of procyanidin trimer $\mathrm{C} 1$ (compound 26) was confirmed by the major fragments at $\mathrm{m} / z 739$ and $\mathrm{m} / z 713$, corresponding to the loss of $126 \mathrm{Da}$ loss of the heterocyclic ring fission reaction and $152 \mathrm{Da}$ loss of the retro-Diels-Alder reaction, respectively. ${ }^{62}$ Compound 25 detected in both modes with observed $\mathrm{m} / \mathrm{z} 289.0717$ in the negative mode was identified as (-)-epicatechin found in all the seeds and the pulp of yellow peppers. The product ion at $\mathrm{m} / \mathrm{z} 245$ was related to the loss of the $\mathrm{CO}_{2}$ moiety, while the fragments at $\mathrm{m} / z 205$ and $\mathrm{m} / z 179$ contributed to the loss of a flavonoid A ring $(84 \mathrm{Da})$ and $\mathrm{B}$ ring $(110 \mathrm{Da})$, respectively. ${ }^{41}$ (-)-Epicatechin has been isolated from cherries, raspberries, and blackberries which was proved to obtain great antioxidant ability. ${ }^{63}$ In the present study, epicatechin, catechin, and related derivatives are the main flavanols identified in bell peppers, which is consistent with the previous study. ${ }^{64}$

Compound $30\left([\mathrm{M}-\mathrm{H}]^{-}, m / z 741.2273\right)$ detected in the seeds of green and red bell peppers was tentatively characterized as naringin $4^{\prime}$-O-glucoside according to the characteristic fragment ions at $\mathrm{m} / z 433$ and $\mathrm{m} / z$ 271, corresponding to the loss of rhamnose plus glucose moieties (308 Da) and rhamnose plus two glucose moieties (470 Da), respectively. ${ }^{65}$ Naringin and its derivatives are the typical flavonoids that are mainly captured in citrus plants exhibiting fantastic antioxidant properties in in vitro and in vivo tests. ${ }^{68}$

2.4.2.2. Flavones, Isoflavonoids, Dihydrochalcones, and Dihydroflavonol Derivatives. 7,4'-Dihydroxyflavone (compound 31 with $[\mathrm{M}+\mathrm{H}]^{+}$at $m / z 255.0641, \mathrm{RT}=13.972$ ) was only detected from the seed of yellow peppers. The confirmation was achieved by analyzing the product ions at $\mathrm{m} /$ $z 227, m / z 199$, and $m / z 171$, corresponding to the loss of CO molecules $(28 \mathrm{Da})$, two $\mathrm{CO}(56 \mathrm{Da})$ molecules, and three $\mathrm{CO}$ (84) molecules from the precursor, respectively. ${ }^{67}$ Two apigenin derivatives (compound 32, apigenin 7-O-glucuronide and compound 33, apigenin 6,7-di-C-glucoside) were also discovered in the peppers. Apigenin 7-O-glucuronide $([\mathrm{M}+$ $\mathrm{H}]^{+}$at $m / z 447.0930$ ) was only identified in YCS in the present study, with the product ions at $m / z 271(\mathrm{M}+\mathrm{H}-$ 176 , loss of a glucuronide moiety) and $m / z 253(\mathrm{M}+\mathrm{H}-$ 176, loss of a glucuronide moiety and $\mathrm{H}_{2} \mathrm{O}$ ), while the confirmation of apigenin 6,8-di-C-glucoside $\left([\mathrm{M}-\mathrm{H}]^{-}\right.$at $\mathrm{m} / z$ 593.1505) was achieved by comparing the MS/MS spectra at $m / z 503(\mathrm{M}-\mathrm{H}-90 \mathrm{Da})$ and $m / z 473(\mathrm{M}-\mathrm{H}-120 \mathrm{Da})$, resulting from the loss of cross-ring cleavages of the glycoside moiety. ${ }^{68}$ Apigenin is a kind of flavone with low toxicity, and it is widespread in the plant kingdom such as onions, celery, and dried parsley, which can help plants to resist the damage of sun light. ${ }^{69,70}$ In addition, $O$-glycosylated apigenin was reported to be abundant in bell peppers, which agreed with our research. ${ }^{71}$

Compound $35\left([\mathrm{M}+\mathrm{H}]^{+}, m / z 489.1387\right)$ was captured in the pulp of green and yellow peppers with the product ions at $m / z 285\left[\mathrm{M}+\mathrm{H}-\mathrm{C}_{2} \mathrm{H}_{2} \mathrm{O}-\mathrm{C}_{6} \mathrm{H}_{10} \mathrm{O}_{5}\right]^{+}$and $m / z 270[\mathrm{M}+\mathrm{H}-$ $\left.\mathrm{C}_{2} \mathrm{H}_{2} \mathrm{O}-\mathrm{C}_{6} \mathrm{H}_{10} \mathrm{O}_{5}-\mathrm{CH}_{3}\right]^{+}$; therefore, the compound was speculated as $6^{\prime \prime} \mathrm{O}$-acetylglycitin. ${ }^{72}$ Isoflavonoids are mainly isolated from soybeans, which are commercially utilized as phytoestrogens. ${ }^{73}$

According to the MS spectra, compound 37 was captured at $[\mathrm{M}+\mathrm{H}]^{+} \mathrm{m} / z 287.0540$, which could be putatively identified as $3^{\prime}$-hydroxygenistein. The product ions were observed at $\mathrm{m} / z$ 


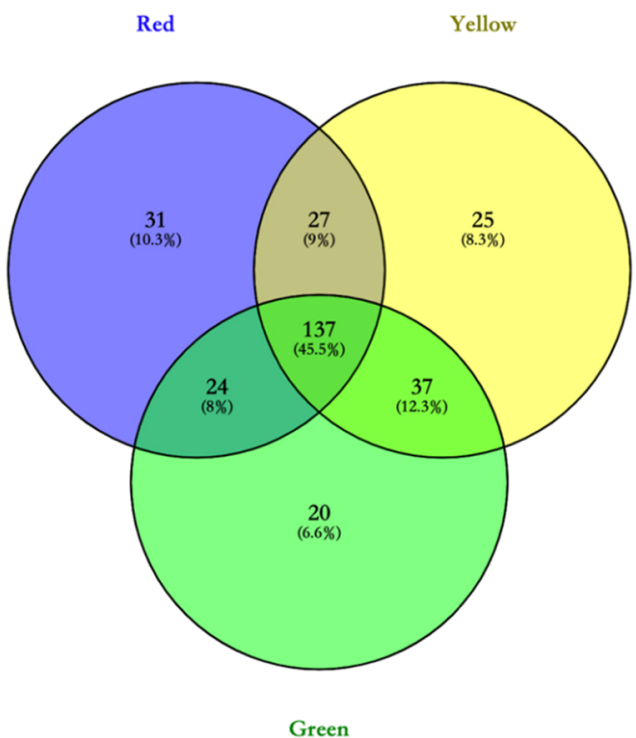

(A)

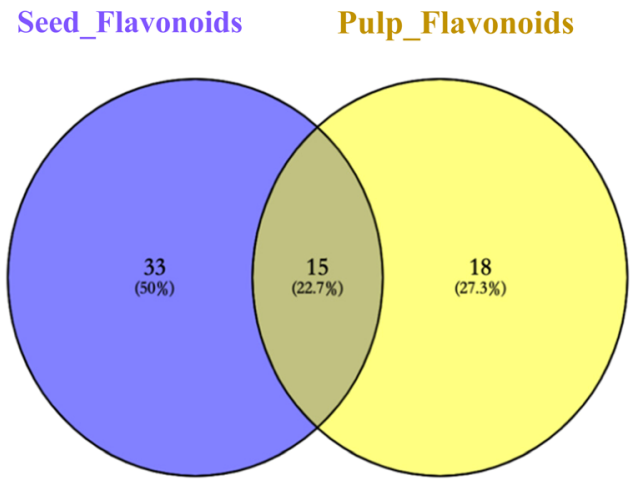

(C)

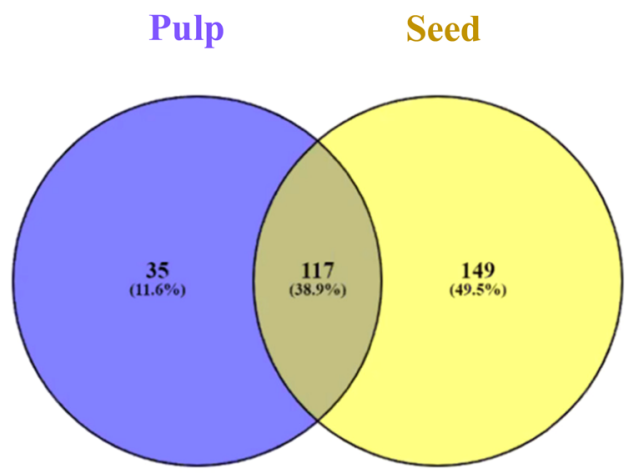

(B)

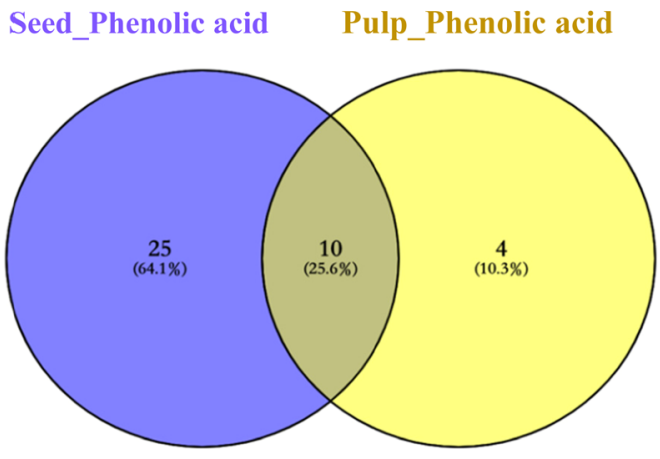

(D)

Figure 1. Venn diagram of phenolic compounds present in different colors of bell peppers. (A) Relations of total phenolic compounds present in three colors of Australian bell peppers; (B) relations of phenolic compounds existing in different parts (pulp and seeds); (C) distribution of flavonoids compounds in different parts of bell peppers (pulp and seeds); (D) distribution of phenolic acids in different parts of bell peppers (pulp and seeds).

269 and $m / z 259$, representing the loss of $\mathrm{H}_{2} \mathrm{O}(18 \mathrm{Da})$ and $\mathrm{CO}(28 \mathrm{Da})$ from the precursor, respectively. ${ }^{74}$ This compound is normally identified from fermented soybean products, ${ }^{75}$ and to the best of our knowledge, this is the first time to characterize this compound from bell peppers. Compound 39 with observed $[\mathrm{M}-\mathrm{H}]^{-} \mathrm{m} / z$ at 443.0976 was inferred as formononetin 7-O-glucuronide because of the main fragments at $\mathrm{m} / z 267$ and $\mathrm{m} / z 252$, resulting from a glucose unit and further loss of $\mathrm{CH}_{3}$ from the parent ion. ${ }^{76}$

Compound 40 (3-hydroxyphloretin 2'-O-glucoside) was the only dihydrochalcone derivative discovered in the present research, and it was captured in the seeds of green and red bell peppers with observed $\mathrm{m} / z 451.1237$ in the $\mathrm{ESI}^{-}$mode. According to the $\mathrm{MS}^{2}$ analysis, two fragments were observed at $\mathrm{m} / z 289$ and $\mathrm{m} / z 273$, corresponding to the loss of the hexosyl moiety and phloretin, respectively. ${ }^{77}$ Previously, 3-hydroxyphloretin 2'-O-glucoside has been isolated from the flesh of apples; however, this is the first time that this compound was identified in bell peppers through LC-MS/MS to the best of our knowledge. ${ }^{77}$

Dihydromyricetin 3-O-rhamnoside (compound 41, $\mathrm{m} / \mathrm{z}$ 465.1036, $\mathrm{ESI}^{-}$) was the only dihydroflavonols isolated from the seeds of green peppers, and the product ion at $\mathrm{m} / \mathrm{z} 301$ generated by cleavage of the rhamnoside group (loss of 164 Da) allowed the further identification of this compound. ${ }^{78}$

2.4.3. Other Polyphenols. Twelve other polyphenols, which were categorized into hydroxybenzaldehydes, curcuminoids, furanocoumarins, hydroxybenzoketones, hydroxycoumarins, tyrosols, and other phenolic compounds, were found in the peppers.

Compound 43 was found in the seeds of green and red bell peppers and was tentatively characterized as demethoxycurcumin with the observed precursor at $[\mathrm{M}-\mathrm{H}]^{-} \mathrm{m} / z$ 337.1087. In the MS/MS fragmentation, the characteristic ion was observed at 217 , corresponding to the loss of $\mathrm{C}_{8} \mathrm{H}_{8} \mathrm{O}(120$ $\mathrm{Da}){ }^{79}$ Demethoxycurcumin is a valuable compound mainly isolated from traditional Chinese medicines Gandou and 
turmeric, and the antioxidant capacity of demethoxycurcumin is remarkable, especially in preventing the unsaturated fatty acid such as linoleic acid from oxidation. ${ }^{79-81}$

Compound 47 (coumarin with $[\mathrm{M}+\mathrm{H}]^{+} \mathrm{m} / z$ at 147.0447, $\mathrm{RT}=15.875$ ) and compound 48 (esculin with $[\mathrm{M}+\mathrm{H}]^{+} \mathrm{m} / z$ at $341.087, \mathrm{RT}=82.047$ ) were two hydroxycoumarins that were only found from the pulp of bell peppers in the $\mathrm{ESI}^{+}$ mode. The characterization of coumarin was supported by its $\mathrm{MS}^{2}$ spectrum, which generated the fragment ions at $\mathrm{m} / z 103$ because of a typical loss of $\mathrm{CO}_{2}$ and the fragment ion at $\mathrm{m} / z$ 91 because of the loss of two $\mathrm{CO}$ units. Coumarin has been identified in Capsicum annuum before, with considerable antioxidant capacity. ${ }^{82}$ In the MS/MS spectrum of compound 48, the product ions were found at $\mathrm{m} / z 179$ and $\mathrm{m} / z 151$ because of the loss of hexose and the sequential loss of $\mathrm{CO}$, respectively, allowing the confirmation of esculin. ${ }^{83}$

A total of four tyrosols were isolated from the bell peppers, and all of them were only captured from the seeds of the bell peppers. Compound $49\left([\mathrm{M}-\mathrm{H}]^{-}\right.$at $\left.m / z 195.0667\right)$ was inferred as 3,4-DHPEA-AC because the major fragment was found at $\mathrm{m} / z 135$ corresponding to the cleavage of $\mathrm{C}_{2} \mathrm{H}_{4} \mathrm{O}_{2}$ $(60 \mathrm{Da}) .{ }^{84}$ Compound $\mathbf{5 1}$ was tentatively characterized as 3,4DHPEA-EDA with the $\mathrm{ESI}^{-}$mode at $\mathrm{m} / z$ 319.1189. In the MS/MS analysis, the product ions were detected at $\mathrm{m} / z 275$ $\left[\mathrm{M}-\mathrm{H}-\mathrm{CH}_{2} \mathrm{CHO}\right]^{-}$and $m / z \quad 195[\mathrm{M}-\mathrm{H}-$ $\left.\mathrm{C}_{5} \mathrm{H}_{6}(\mathrm{CHO})_{2}\right]^{-85}$ Compound 52 at $\mathrm{m} / z 315.1072$ in the $\mathrm{ESI}^{-}$mode, which yielded the main product ions at $\mathrm{m} / z 153$ and $m / z 123$, corresponding to the loss of a hexose moiety and a further loss of $\mathrm{CH}_{2} \mathrm{O}$ group, respectively, was characterized as hydroxytyrosol 4-O-glucoside. ${ }^{86}$ Compound $\mathbf{5 3}$ showing precursor ion $[\mathrm{M}-\mathrm{H}]^{-}$at $\mathrm{m} / z 537.1047$ was confirmed as lithospermic acid found in the seeds of green and yellow peppers based on the $\mathrm{MS}^{2}$ fragmentation at $\mathrm{m} / z 493$ (loss of $\mathrm{CO}_{2}$ ), $m / z 339$ (loss of a danshensu (DSS)), and 295 (loss of a DSS and $\left.\mathrm{CO}_{2}\right){ }^{87}$

2.4.4. Lignans and Stilbenes. A total of six lignans were identified in bell peppers. Compound $\mathbf{5 5}$ detected in the $\mathrm{ESI}^{+}$ mode at $\mathrm{m} / z 403.2100$ was inferred as schisanhenol based on the product ions at $m / z 385\left[\mathrm{M}+\mathrm{H}-\mathrm{H}_{2} \mathrm{O}\right]^{+}, m / z 354[\mathrm{M}+$ $\left.\mathrm{H}-\mathrm{H}_{2} \mathrm{O}-\mathrm{OCH}_{3}\right]^{+}$, and $m / z 331\left[\mathrm{M}+\mathrm{H}-\mathrm{H}_{2} \mathrm{O}-\mathrm{C}_{4} \mathrm{H}_{6}\right]^{+} .{ }^{+}$ Compounds 56, 58, and 59 were three compounds that were isolated from the seeds of peppers only. Schisandrin C (compound 56, $\mathrm{m} / z$ 385.1651) was profiled in the positive mode, while the major fragments were identified at $m / z 370$, $m / z 315$, and $m / z 300$, corresponding to the loss of $\mathrm{CH}_{3}$, $\mathrm{C}_{5} \mathrm{H}_{10}$, and $\mathrm{CH}_{3}$ plus $\mathrm{C}_{5} \mathrm{H}_{10}$, respectively, from the precursor. ${ }^{88}$ Compound 58 was only identified in the seeds of yellow bell peppers with the $\mathrm{ESI}^{-}$mode at $m / z 357.1377$, and the main fragments were observed at $m / z 342\left[\mathrm{M}-\mathrm{H}-\mathrm{CH}_{3}\right]^{-}, \mathrm{m} / z$ $327\left[\mathrm{M}-\mathrm{H}-\mathrm{C}_{2} \mathrm{H}_{6}\right]^{-}, m / z 313\left[\mathrm{M}-\mathrm{H}-\mathrm{CO}_{2}\right]^{-}$, and $m / z$ $221\left[\mathrm{M}-\mathrm{H}-\mathrm{C}_{8} \mathrm{H}_{8} \mathrm{O}_{2}\right]^{-}$, allowing the confirmation as matairesinol. ${ }^{53}$ Compound 59 (resveratrol 3-O-glucoside) was the only stilbenes identified in all the seeds of bell peppers with the negative mode at $\mathrm{m} / z$ 389.1228. The confirmation was achieved by the MS/MS fragmentation that resulted in the product ion at $\mathrm{m} / z 227$ (loss of $162 \mathrm{Da}$ ), indicating the presence of a glucose monosaccharide side group. ${ }^{89}$ The presence of resveratrol in Capsicum spp. has been proved in the previous study by applying the HPLC technique and standards, and the bell pepper exhibited a significantly higher value than the other species. ${ }^{64}$

The screening and profiling of the phenolic compounds provide an overall idea of antioxidation compounds in three colors of Australian bell peppers. Some of them have already been proved to obtain strong antioxidation properties, illustrating that bell peppers could be a good source of phenolic compounds engaged in the food, feed, cosmetics, and medicinal industries.

2.5. Distribution of Phenolic Compound-Venn Diagram. The LC-ESI/QTOF-MS/MS experiment scoped the individual compound among bell peppers; however, the difference of phenolic compounds between bell peppers required a better analysis. The Venn diagrams summarized the distribution of phenolic compounds in bell pepper varieties and the difference between seeds and pulps (Figure 1).

A total of 301 phenolic compounds were identified in bell pepper samples, while $137(45.5 \%)$ common phenolic compounds were identified in all samples. Most exclusive compounds were found in red bell peppers (10.3\%) followed by yellow $(8.3 \%)$ and green $(6.6 \%)$ peppers sequentially. Previous studies also suggested that red bell peppers exhibited a higher phenolic content as compared to yellow and green peppers. ${ }^{16,90}$

Figure 1B showed that pulp and seed portions shared 117 (38.9\%) common phenolic compounds. Remarkably, a total of 149 (49.5\%) were found exclusively in seeds, while 35 unique compounds were discovered in pulps. The same trend was also observed in previous research by Sayin, ${ }^{91}$ which indicated that the seed portions of bell peppers obtain a higher content of phenolic compounds than the pulp portion. The distributions of flavonoids and phenolic acids in seed and pulp are shown in Figure 1C,D; according to the figures, seeds of bell peppers had higher amounts of both flavonoids and phenolic acid, which accounted for 50 and $64.1 \%$, respectively.

Overall, the seeds had higher flavonoids, phenolic acids, and total polyphenols than the pulp portion, which is in agreement with previous research. ${ }^{11}$ Although the seed of bell peppers is regarded as food waste, it presents the potential of being utilized in the food and pharmaceutical industries because of the phenolic compounds and antioxidant capacity.

2.6. Heat Map and Hierarchical Clustering Phenolic Compound Analysis. A heat map (Figure 2) was conducted along with hierarchical clusters for further analyzing HPLCPDA-quantified phenolic compounds in bell peppers. A total of 10 phenolic compounds consisting of five phenolic acids and five flavonoids were quantified. The color represents the average content of phenolic compounds of samples. Correlation was used as the distance measure for determining the similarity between samples, and the axis of the map showed the similarity among the samples.

In the heat map, the samples were clustered in BP-1 (including YCS and YCP) and BP-2 (including GCS, RCS, GCP, and RCP) because they have a high level of difference in phenolic contents between the groups. Among group BP-2, the phenolic contents of GCS were closer to RCS, while GCP and RCP have more similar phenolic quantities.

The phenolic compounds were clustered into three groups (PC-1, PC-2, and PC-3) and several subgroups based on the concentration similarity in the samples. Gallic acid and syringic acid composed the PC-1 cluster, both of which exhibited the highest concentration in YCS and YCP, and the lowest in GCP and RCP. The PC-2 cluster consisted of caffeic acid and catechin, showing the highest concentration in GCS and RCS. A previous study also concluded that the highest concentration of catechin was found in red capsicum seeds, which was in agreement with our finding. ${ }^{64}$ Six targeted phenolic com- 


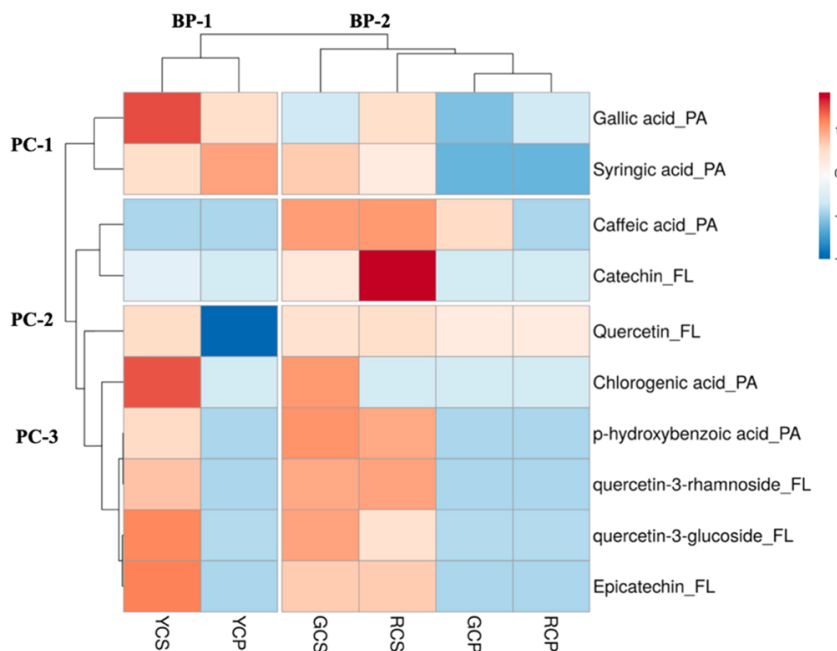

Figure 2. Heatmap showing the distribution of target phenolic compounds and the concentration of these compounds. More the red color is the higher concentration of the target phenolic compounds; more the blue color is the lower the concentration of the target phenolic compounds. BP 1-2: bell pepper cluster; PC 1-3: phenolic acid cluster; PA-phenolic acid; FL-flavonoid. Seeds of green bell peppers "GCS"; pulp of green bell peppers "GCP"; seeds of yellow bell peppers "YCS"; pulp of yellow bell peppers "YCP"; seeds of red bell peppers "RCS"; pulp of red bell peppers "RCP".

pounds formed the cluster PC-3, including two phenolic acids (chlorogenic acid and $p$-hydroxybenzoic acid) and four flavonoids (quercetin, quercetin-3-rhamnoside, quercetin-3glucoside, and epicatechin). The concentration of several phenolic contents in Jalapeño (Capsicum annuum) was determined using HPLC in a previous study conducted by Sandoval-Castro et al., ${ }^{92}$ and they demonstrated that phenolic acids mainly existed in the seeds of the bell peppers, which was consistent with our findings. In terms of flavonoids, epicatechin, quercetin-3-glucoside, and quercetin-3-rhamnoside were found abundant in seeds of all bell peppers. Our findings were supported by the previous studies, which found that quercetin-3-glucoside primarily existed in red peppers (Capsicum annuum L.) and the catechin was accumulated in the seed of Capsicum annuum L. ${ }^{33,93}$

\section{MATERIALS AND METHODS}

3.1. Chemicals and Reagents. All the chemicals and reagents were of analytical grade and produced by SigmaAldrich (Castle Hill, NSW, Australia). Ethanol and analyticalgrade acetonitrile were produced by Merck KGaA (Darmstadt, Germany). The standards for antioxidant assays were purchased from Sigma-Aldrich (St. Louis, MO, USA), including gallic acid, quercetin, catechin, and L-ascorbic acid. Folin and Ciocalteu's phenol, aluminum chloride hexahydrate, vanillin, DPPH, ferric(III) chloride anhydrous, and ABTS, were produced by Sigma-Aldrich (St. Louis, MO, USA). Sodium carbonate anhydrous was from Gilman Australia (SA, Australia), and sodium acetate hydrated was from Ajax Finechem (VIC, Australia). Sulfuric acid 98\% was produced by RCI Labscan (Rongmuang, Thailand). In terms of the mobile phases of the LC-MS/MS experiment, acetic acid was purchased from Sigma-Aldrich (St. Louis, MO, USA) and acetonitrile was from LiChrosolv (Darmstadt, Germany). Analytical-grade standards for HPLC-PDA quantification analysis were purchased from Sigma-Aldrich (St. Louis, MO,
USA) including catechin, quercetin 3-O-galactoside, quercetin 3-O-glucuronide, kaempferol 3-O-glucoside, quercetin, kaempferol, protocatechuic acid, $p$-hydroxybenzoic acid, chlorogenic acid, caffeic acid, syringic acid, coumaric acid, and ferulic acid.

3.2. Sample Preparation. Three types of Australiangrown bell peppers (green, red, and yellow) were collected from a local market in August 2019 (Kensington VIC, Australia). The fresh bell peppers were separated into seeds and pulps. The pulp parts were blended to slurry separately with a 1.5 L blender (Russell Hobbs Classic, mode DZ-1613, Melbourne, VIC, Australia). The slurry was kept at $-20{ }^{\circ} \mathrm{C}$ for further analysis. The seed part was separated followed by dehydration at $-45^{\circ} \mathrm{C} / 50 \mathrm{MPa}$ using a Dynavac engineering FD3 Freeze Drier (Belmont, W.A., Australia) and an Edwards RV12 oil-sealed rotary vane pump (Bolton, England). After lyophilization, the seeds were ground into powder and stored at $-20{ }^{\circ} \mathrm{C}$ for further analysis.

3.3. Extraction of Phenolic Compounds. The extracts were prepared based on a previous study ${ }^{94}$ with some modifications. The samples were homogenized with an UltraTurrax T25 Homogenizer (IKA, Staufen, Germany) at 10,000 rpm for $30 \mathrm{~s}$. After that, the samples were extracted in $80 \%$ ethanol and were incubated in a ZWYR-240 incubator shaker (Labwit, Ashwood, VIC, Australia) with $120 \mathrm{rpm}$ at $4{ }^{\circ} \mathrm{C}$ for $12 \mathrm{~h}$ followed by the centrifugation (Hettich Refrigerated Centrifuge) at $10,000 \mathrm{rpm}$ for $15 \mathrm{~min}$. The supernatant was collected and stored at $-20{ }^{\circ} \mathrm{C}$ for further analysis. All the results were gained based on fresh weight. For HPLC and LCMS experiments, the extracts were purified using a $0.22 \mu \mathrm{m}$ syringe filter (Thermo Fisher Scientific Inc., Waltham, MA, USA).

3.4. Phenolic Compound Estimation and Antioxidant Assays. TPC, TFC, and TTC assays were performed to estimate the phenolic contents of the samples, while the antioxidant potentials were determined through DPPH, ABTS, FRAP, and TAC assays. The absorbance was measured using a Multiskan Go microplate photometer (Thermo Fisher Scientific, Waltham, MA, USA).

3.4.1. Determination of TPC. The TPC was estimated by following the Folin-Ciocalteu method with modifications. ${ }^{19}$ Folin-Ciocalteu reagent $(25 \mu \mathrm{L})$, Milli-Q water $(200 \mu \mathrm{L})$, and $25 \mu \mathrm{L}$ of standard/extracts were added into a 96-well plate (Costar, Corning, NY, USA) for triplicate and incubated for 5 min at room temperature. Then, $10 \%(\mathrm{w} / \mathrm{w})$ sodium carbonate $(25 \mu \mathrm{L})$ was added and stored in a dark environment for $1 \mathrm{~h}$ at room temperature. The absorbance was read at $765 \mathrm{~nm}$ against a blank using a Multiskan Go microplate photometer. The calibration curve of the standard reagent (gallic acid, ranging from 0 to $200 \mu \mathrm{g} / \mathrm{mL}$ ) was plotted by converting the absorbance. The TPC values were calculated with the standard curve, and the results were presented as mg of gallic acid equivalents per gram \pm standard error $(\mathrm{mg}$ GAE/g $\pm \mathrm{SE})$ based on the fresh weight (f.w.).

3.4.2. Determination of TFC. Modified aluminum chloride method $^{95}$ was used to evaluate the TFC of the bell peppers. Extracts $(80 \mu \mathrm{L})$ and standard were mixed with $2 \%(\mathrm{w} / \mathrm{v})$ aluminum chloride ethanolic solution $(80 \mu \mathrm{L})$ and $120 \mu \mathrm{L}$ of sodium acetate $(50 \mathrm{mg} / \mathrm{mL})$. The mixtures were incubated in darkness at room temperature for $1 \mathrm{~h}$, and the results were measured at $440 \mathrm{~nm}$. The values of TFC were expressed in quercetin equivalent $(\mu \mathrm{g} \mathrm{QE} / \mathrm{g})$ in fresh weight, and the concentration of quercetin was ranging from $0-50 \mu \mathrm{g} / \mathrm{mL}$. 
3.4.3. Determination of $\Pi T C$. The determination of TTC was based on the method developed by Zou, et al. ${ }^{96}$ First of all, $25 \mu \mathrm{L}$ samples and standard were mixed with $150 \mu \mathrm{L}$ of $4 \%$ methanolic vanillin solution (w/v). After that, $25 \mu \mathrm{L}$ of $32 \%$ $(\mathrm{v} / \mathrm{v})$ sulfuric acid (diluted with methanol) was added into a 96-well plate and incubated at $25{ }^{\circ} \mathrm{C}$ for $15 \mathrm{~min}$. The standard curve was calculated with catechin standard ranging from $0-$ $1000 \mu \mathrm{g} / \mathrm{mL}$. The absorbance was measured at $500 \mathrm{~nm}$, and the tannin content was calculated according to the calibration curve with the unit of $\mathrm{mg} \mathrm{CE} / \mathrm{g}_{\text {f.w. }}$.

3.4.4. DPPH Antioxidant Assay. The free radical scavenging ability was examined by DPPH assay by adopting the previous method $^{19}$ with slight modifications. First, $40 \mu \mathrm{L}$ of extracts/ standard and $260 \mu \mathrm{L}$ of DPPH radical ethanolic solution were mixed in a 96-well plate. Second, the mixtures were incubated for $30 \mathrm{~min}$ at room temperature before measuring the absorbance at $517 \mathrm{~nm}$. The standard curve was developed under the concentration of the ascorbic acid solution from $0-$ $50 \mu \mathrm{g} / \mathrm{mL}$, while the results were calculated according to the equivalent of ascorbic acid and expressed as $\mathrm{mg}$ of ascorbic acid equivalents per $\mathrm{g}\left(\mathrm{mg} \mathrm{AAE} / \mathrm{g}_{\text {f.w. }}\right)$.

3.4.5. ABTS+ Radical Scavenging Assay. $\mathrm{ABTS}^{+}$radical cation decolorization was engaged to assess the radical scavenging activity of samples, and the method was previously described by $\mathrm{Ma}$ and Dunshea ${ }^{97}$ with few modifications. Free radical scavenging capacity was based on the positive charges in the $\mathrm{ABTS}^{+}$solution. The $\mathrm{ABTS}^{+}$stock solution was prepared by mixing $88 \mu \mathrm{L}$ of $140 \mathrm{mM}$ potassium and $5 \mathrm{~mL}$ of $7 \mathrm{mM}$ of ABTS solution. After that, the reaction mixture was stored in darkness for $16 \mathrm{~h}$. Ten microliters of prepared extracts/standard would be mixed with $290 \mu \mathrm{L}$ of $\mathrm{ABTS}^{+}$ solutions. The absorbance was measured at $734 \mathrm{~nm}$ after the incubation at room temperature for $6 \mathrm{~min}$. The results were shown with $\mathrm{mg}$ ascorbic acid equivalent per gram of fresh samples $\left(\mathrm{AAE} / \mathrm{g}_{\text {f.w. }}\right)$.

3.4.6. FRAP Assay. The ferric reducing capacity of the compounds was determined through the FRAP method of Benzie, et al. Benzie and Strain ${ }^{98}$ with modifications. Twenty microliters of samples/standard were mixed with $280 \mu \mathrm{L}$ of FRAP reagent, which was produced by mixing $300 \mathrm{mM}$ acetate buffer, $10 \mathrm{mM}$ TPTZ solution, and $20 \mathrm{mM}$ ferric chloride in a ratio of $10: 1: 1(\mathrm{v} / \mathrm{v} / \mathrm{v})$. The mixture was then incubated for 10 $\min$ at $37{ }^{\circ} \mathrm{C}$, and the absorbance was obtained at $593 \mathrm{~nm}$. The standard curve was plotted using ascorbic acid (ranging from 0 to $50 \mu \mathrm{g} / \mathrm{mL}$ ), and the results were expressed as the mg AAE/ $\mathrm{g}_{\text {f.w. }}$.

3.4.7. TAC Assay. TAC assay was modified based on the methods of Jan, et al. ${ }^{18}$ First, $0.6 \mathrm{M}$ sulfuric acid, $28 \mathrm{mM}$ sodium phosphate, and $4 \mathrm{mM}$ ammonium molybdate were mixed in a ratio of $1: 1: 1(\mathrm{v} / \mathrm{v} / \mathrm{v})$ to prepare the phosphomolybdate reagent. Then, $20 \mu \mathrm{L}$ of samples and standard were mixed with $280 \mu \mathrm{L}$ of preparation dye solution followed by incubation at $95{ }^{\circ} \mathrm{C}$ for $90 \mathrm{~min}$, and the absorbance was observed at $765 \mathrm{~nm}$. The standard curve was constructed with the $0-300 \mu \mathrm{g} / \mathrm{mL}$ ascorbic acids, and the results would be described as mg AAE per fresh gram.

3.5. LC-ESI-QTOF-MS/MS Characterization of Phenolic Compounds. The LC-MS analysis was carried out with a 1200 series HPLC (Agilent Technologies, Santa Clara, CA, USA) equipped with an Agilent 6520 I Accurate-Mass QTOF detector, (Agilent Technologies, Santa Clara, CA, USA) via an ESI and was based on the method of $\mathrm{Gu}$, et al. ${ }^{95} \mathrm{~A}$ Synergi Hydro-RP $80 \AA$, LC column $(250 \mathrm{~mm} \times 4.6 \mathrm{~mm}, 4$ $\mu \mathrm{m}$ ) (Phenomenex, Lane Cove, NSW, Australia) was applied to isolate the compounds at room temperature, and the multisampler was set at $10{ }^{\circ} \mathrm{C}$ with an injection volume of 6 $\mu \mathrm{L}$. The composition of mobile phase A consisted of acetic acid and water in a ratio of $0.5: 99.5 \mathrm{v} / \mathrm{v}$. The mobile phase $\mathrm{B}$ was a mixture with three compounds which were acetonitrile, acetic acid, and water in a ratio of 50:49.5:0.5 (v/v/v). The whole gradient profile was $85 \mathrm{~min}$ with a flow rate of $0.8 \mathrm{~mL} /$ min and described as follows: 0 min with $10 \%$ B, 20 min with $25 \%$ B, 30 min with $35 \%$ B, 40 min with $40 \%$ B, 70 min with $55 \%$ B, 75 min with $80 \%$ B, 77 min with $100 \%$ B, 79 min with $100 \% \mathrm{~B}, 82-85 \mathrm{~min}$ with isocratic $10 \% \mathrm{~B}$ to equilibrate the column. The pressure of nebulization gas was set at 45 psi with a flow rate of $5 \mathrm{~L} / \mathrm{min}$ at $300{ }^{\circ} \mathrm{C}$. At the same time, the sheath gas was set at a flow rate of $11 \mathrm{~L} / \mathrm{min}$ at $250^{\circ} \mathrm{C}$. The mass scan range was from $50-1300 \mathrm{~m} / z$. MS/MS analyses were carried out in automatic mode with collision energy $(10,15$, and 30 $\mathrm{eV}$ ) for fragmentation. Peak identification was performed in both positive and negative modes separately while the instrument control, data acquisition, and processing were performed using MassHunter workstation software (Qualitative Analysis, version B.03.01) (Agilent Technologies, Santa Clara, CA, USA).

3.6. HPLC-PDA Quantification Analysis. The phenolic content quantification was carried out using an Agilent 1200 HPLC system attached with a photodiode array detector. The parameters of HPLC were set as the same as those of LC-MS mentioned above except the injection volume was $20 \mu \mathrm{L}$. The absorbance of samples was detected under three wavelengths of 280,320 , and $370 \mathrm{~nm}$ simultaneously with $1.25 \mathrm{scan} / \mathrm{s}$ (peak width $=0.2 \mathrm{~min}$ ) spectral acquisition rate. The standard curve would be drawn based on the different concentrations of the standards. The data and analysis were carried out with the help of the Agilent LC-ESI-QTOF/MS MassHunter workstation (Qualitative Analysis, version B.03.01) (Agilent Technologies, Santa Clara, CA, USA).

3.7. Statistics Analysis. The results of phenolic compound estimation and antioxidant capacity evaluation were obtained with three parallel experiments $(n=3)$. The results were displayed with mean \pm standard deviation. The significance of each result was measured based on one-way ANOVA $(p<$ 0.05 ) with Tukey's honestly significant difference under the help of Minitab Statistical Software for Windows Version 18.0 (Minitab Inc., USA).

\section{CONCLUSIONS}

Overall, pulps and seeds of yellow, green, and red bell peppers were proved to be abundant in phenolic compounds with considerable antioxidant potential by various in vitro assays. The pulp of red bell peppers exhibited the highest phenolic compound content and antioxidant potential in all the assays including TPC, TFC, TTC, TAC, DPPH, ABTS, and FRAP. The LC-MS also engaged to characterize the individual phenolic compounds in bell peppers, and a total of 59 phenolic compounds were isolated from all parts of bell peppers. Ten phenolic compounds were quantified by HLC-PDA, and the seeds exhibited a relatively higher concentration of most compounds than pulps did. According to the results, different parts of bell peppers could be good sources of phenolic compounds with remarkable antioxidant capacity in the food, cosmetics, pharmaceutical, and nutraceutical industries. In addition, the methodology provided in this study could be an example for other research studies in the area that characterize 
phenolic compounds in plants. Future studies, including toxicological and animal studies, can support and boost the commercialization of these compounds.

\section{ASSOCIATED CONTENT}

\section{SI Supporting Information}

The Supporting Information is available free of charge at https://pubs.acs.org/doi/10.1021/acsomega.1c06532.

LC-ESI-QTOF-MS/MS basic peak chromatograph for characterization of phenolic compounds of Australiangrown bell peppers; (a) the pulp of green bell peppers in the negative ionization mode; (b) the pulp of red bell peppers in the negative ionization mode; (c) the pulp of yellow bell peppers in the negative ionization mode; (d) the pulp of green bell peppers in the positive ionization mode; (e) the pulp of red bell peppers in the positive ionization mode; (f) the pulp of yellow bell peppers in the positive ionization mode; $(\mathrm{g})$ the seed of green bell peppers in the negative ionization mode; $(h)$ the seed of red bell peppers in the negative ionization mode; (i) the seed of yellow bell peppers in the negative ionization mode; $(j)$ the seed of green bell peppers in the positive ionization mode; $(\mathrm{k})$ the seed of red bell peppers in the positive ionization mode; and (l) the seed of yellow bell peppers in the positive ionization mode (PDF)

\section{AUTHOR INFORMATION}

\section{Corresponding Authors}

Abdur Rauf - Department of Chemistry, University of Swabi, Swabi, Khyber Pakhtunkhwa 23561, Pakistan; (1) orcid.org/ 0000-0003-2429-5491; Email: abdurrauf@uoswabi.edu.pk

Hafiz Ansar Rasul Suleria - School of Agriculture and Food, Faculty of Veterinary and Agricultural Sciences, The University of Melbourne, Parkville, Victoria 3010, Australia; Email: hafiz.suleria@unimelb.edu.au

\section{Authors}

Zexing Leng - School of Agriculture and Food, Faculty of Veterinary and Agricultural Sciences, The University of Melbourne, Parkville, Victoria 3010, Australia

Biming Zhong - School of Agriculture and Food, Faculty of Veterinary and Agricultural Sciences, The University of Melbourne, Parkville, Victoria 3010, Australia

Hanjing Wu - School of Agriculture and Food, Faculty of Veterinary and Agricultural Sciences, The University of Melbourne, Parkville, Victoria 3010, Australia

Ziyao Liu - School of Agriculture and Food, Faculty of Veterinary and Agricultural Sciences, The University of Melbourne, Parkville, Victoria 3010, Australia; (1) orcid.org/ 0000-0002-5332-6333

Sami Bawazeer - Department of Pharmacognosy, Faculty of Pharmacy, Umm Al-Qura University, Makkah 21421, Kingdom of Saudi Arabia

Complete contact information is available at:

https://pubs.acs.org/10.1021/acsomega.1c06532

\section{Author Contributions}

Conceptualization, Z.L.; B.Z.; and H.A.R.S.; methodology, Z.L.; B.Z.; H.W.; A.R.; and H.A.R.S.; validation, Z.L.; B.Z.; Z.L.; and H.A.R.S.; formal analysis, Z.L.; B.M.; and H.W.; investigation, Z.L.; B.Z.; and H.A.R.S.; resources and data curation and original draft preparation, Z.L.; B.M.; H.W.; Z.L.;
A.R.; S.A.; and H.A.R.S. All authors read the paper and agreed to process for publication. Z.L. and B.Z. contributed equally to this work.

\section{Funding}

This research was funded by the University of Melbourne under the "McKenzie Fellowship Scheme" (Grant No. UoM18/21), the "Richard WS Nicholas Agricultural Science Scholarship" and the "Faculty Research Initiative Funds" funded by the Faculty of Veterinary and Agricultural Sciences, The University of Melbourne, Australia, and "The Alfred Deakin Research Fellowship” funded by Deakin University, Australia.

\section{Notes}

The authors declare no competing financial interest.

\section{ACKNOWLEDGMENTS}

We would like to thank Nicholas Williamson, Shuai Nie, and Michael Leeming from the Mass Spectrometry and Proteomics Facility, Bio21 Molecular Science and Biotechnology Institute, the University of Melbourne, VIC, Australia for providing access and support for the use of HPLC-PDA and LC-ESIQTOF-MS/MS and data analysis.

\section{REFERENCES}

(1) Salehi, B.; Hernández-Álvarez, A. J.; del Mar Contreras, M.; Martorell, M.; Ramírez-Alarcón, K.; Melgar-Lalanne, G.; Matthews, K. R.; Sharifi-Rad, M.; Setzer, W. N.; Nadeem, M.; Yousaf, Z.; SharifiRad, J. Potential Phytopharmacy and Food Applications of Capsicum spp.: A Comprehensive Review. Nat. Prod. Commun. 2018, 13, 33.

(2) Ali, Q.; Ashfaq, M. A.; Khan, M. T. I. In An Economic Analysis of Off-Season Capsicum/Bell Pepper Production in Punjab; Pakistan, 2016.

(3) Agricultural Commodities, Australia, 2015-16. Australian Bureau of Statistics: CANBERRA 2018.

(4) Agricultural Commodities, Australia, 2016-17. Australian Bureau of Statics: CANBERRA 2019.

(5) Pérez-López, A. J.; del Amor, F. M.; Serrano-Martínez, A.; Fortea, M. I.; Núñez-Delicado, E. Influence of agricultural practices on the quality of sweet pepper fruits as affected by the maturity stage. J. Sci. Food Agric. 2007, 87, 2075-2080.

(6) Rodrigues, C. A.; Nicácio, A. E.; Jardim, I. C. S. F.; Visentainer, J. V.; Maldaner, L. Determination of Phenolic Compounds in Red Sweet Pepper (Capsicum annuum L.) Using a Modified QuEChERS Method and UHPLC-MS/MS Analysis and Its Relation to Antioxidant Activity. J. Braz. Chem. Soc. 2019, 30, 1229-1240.

(7) Puvača, N.; Ljubojević, D.; Kostadinović, L. J.; Lević, J.; Nikolova, N.; Miščević, B. Spices and herbs in broilers nutrition: hot red pepper (Capsicum annuum L.) and its mode of action. World's Poult. Sci. J. 2015, 71, 683-688.

(8) Trisno, J.; Jamsari, R.; Yusniwati. Calli Induction of Some Chili Pepper (Capsicum annuum L.) Genotypes as Material for Genetic Transformation. Int. J. Agric. Sci. 2017, 1, 6.

(9) Cervantes-Paz, B.; Yahia, E. M.; de Jesús Ornelas-Paz, J.; Victoria-Campos, C. I.; Ibarra-Junquera, V.; Pérez-Martínez, J. D.; Escalante-Minakata, P. Antioxidant activity and content of chlorophylls and carotenoids in raw and heat-processed Jalapeño peppers at intermediate stages of ripening. Food Chem. 2014, 146, 188-196.

(10) Robards, K.; Prenzler, P. D.; Tucker, G.; Swatsitang, P.; Glover, $\mathrm{W}$. Phenolic compounds and their role in oxidative processes in fruits. Food Chem. 1999, 66, 401-436.

(11) Sora, G. T. S.; Haminiuk, C. W. I.; da Silva, M. V.; Zielinski, A. A. F.; Gonçalves, G. A.; Bracht, A.; Peralta, R. M. A comparative study of the capsaicinoid and phenolic contents and in vitro antioxidant activities of the peppers of the genus Capsicum: an application of chemometrics. J. Food Sci. Technol. 2015, 52, 8086-8094. 
(12) Hou, B.-Z.; Li, C.-L.; Han, Y.-Y.; Shen, Y.-Y. Characterization of the hot pepper (Capsicum frutescens) fruit ripening regulated by ethylene and ABA. BMC Plant Biol. 2018, 18, 162.

(13) Manach, C.; Scalbert, A.; Morand, C.; Rémésy, C.; Jiménez, L. Polyphenols: food sources and bioavailability. Am. J. Clin. Nutr. 2004, 79, 727-747.

(14) Cortés-Estrada, C.; Gallardo-Velazquez, T.; Osorio-Revilla, G.; Castañeda-Pérez, E.; Meza-Márquez, O.; Cortez, L.; HernándezMartínez, M. Prediction of total phenolics, ascorbic acid, antioxidant capacities, and total soluble solids of Capsicum annuum L. (bell pepper) juice by FT-MIR and multivariate analysis. Lebensm.-Wiss. Technol 2020, 126, No. 109285

(15) Huyut, Z.; Beydemir, Ş.; Gülçin, İ. Antioxidant and Antiradical Properties of Selected Flavonoids and Phenolic Compounds. Biochem. Res. Int. 2017, 2017, No. 7616791.

(16) Chávez-Mendoza, C.; Sanchez, E.; Muñoz-Marquez, E.; SidaArreola, J. P.; Flores-Cordova, M. A. Bioactive compounds and antioxidant activity in different grafted varieties of bell pepper. Antioxidants 2015, 4, 427-446.

(17) Blanco-Ríos, A. K.; Medina-Juárez, L. Á.; González-Aguilar, G. A.; Gámez-Meza, N. Antioxidant activity of the phenolic and oily fractions of different sweet bell peppers. J. Mex. Chem. Soc. 2013, 57, 137-143.

(18) Jan, S.; Khan, M. R.; Rashid, U.; Bokhari, J. Assessment of antioxidant potential, total phenolics and flavonoids of different solvent fractions of monotheca buxifolia fruit. Osong Public Health Res. Perspect. 2013, 4, 246-254.

(19) Yazdizadeh Shotorbani, N.; Jamei, R.; Heidari, R. Antioxidant activities of two sweet pepper Capsicum annuum L.varieties phenolic extracts and the effects of thermal treatment. Avicenna J. Phytomed. 2013, 3, 25-34.

(20) Abu-Reidah, I. M.; Ali-Shtayeh, M. S.; Jamous, R. M.; ArráezRomán, D.; Segura-Carretero, A. HPLC-DAD-ESI-MS/MS screening of bioactive components from Rhus coriaria L. (Sumac) fruits. Food Chem. 2015, 166, 179-191.

(21) Park, J.-H.; Jeon, G.-I.; Kim, J.-M.; Park, E. Antioxidant activity and antiproliferative action of methanol extracts of 4 different colored bell peppers (Capsicum annuum L.). Food Sci. Biotechnol. 2012, 21, 543-550.

(22) Zhuang, Y.; Chen, L.; Sun, L.; Cao, J. Bioactive characteristics and antioxidant activities of nine peppers. J. Funct. Foods 2012, 4, $331-338$.

(23) Asami, D. K.; Hong, Y. J.; Barrett, D. M.; Mitchell, A. E. Comparison of the total phenolic and ascorbic acid content of freezedried and air-dried marionberry, strawberry, and corn grown using conventional, organic, and sustainable agricultural practices. J. Agric. Food Chem. 2003, 51, 1237-1241.

(24) Navarro, J. M.; Flores, P.; Garrido, C.; Martinez, V. Changes in the contents of antioxidant compounds in pepper fruits at different ripening stages, as affected by salinity. Food Chem. 2006, 96, 66-73.

(25) Tungmunnithum, D.; Thongboonyou, A.; Pholboon, A.; Yangsabai, A. Flavonoids and Other Phenolic Compounds from Medicinal Plants for Pharmaceutical and Medical Aspects: An Overview. Medicines 2018, 5, 93.

(26) Sun, T.; Wu, C. T.; Janes, M.; Prinyawiwatkul, W.; No, H. K. Antioxidant Activities of Different Colored Sweet Bell Peppers (Capsicum annuum L.). J. Food Sci. 2007, 72, S98-S102.

(27) Mahdavian, K.; Ghorbanli, M.; Kalantari, K. M. The effects of ultraviolet radiation on the contents of chlorophyll, flavonoid, anthocyanin and proline in Capsicum annuum L. Turk. J. Bot. 2008, $32,25-33$.

(28) Garcia-Mier, L.; Jimenez-Garcia, S. N.; Guevara-González, R. G.; Feregrino-Perez, A. A.; Contreras-Medina, L. M.; Torres-Pacheco, I. Elicitor Mixtures Significantly Increase Bioactive Compounds, Antioxidant Activity, and Quality Parameters in Sweet Bell Pepper. J. Chem. 2015, 2015, No. 269296.

(29) Shiva Ram, B.; Bo-Deul, J.; Hum-Young, B.; Young-Sang, L. Ripening-dependent Changes in Phytonutrients and Antioxidant
Activity of Red Pepper (Capsicum annuum L.) Fruits Cultivated under Open-field Conditions. HortScience 2013, 48, 1275-1282.

(30) Howard, L. R.; Talcott, S. T.; Brenes, C. H.; Villalon, B. Changes in phytochemical and antioxidant activity of selected pepper cultivars (Capsicum species) as influenced by maturity. J. Agric. Food Chem. 2000, 48, 1713-1720.

(31) Ghasemnezhad, M.; Sherafati, M.; Payvast, G. A. Variation in phenolic compounds, ascorbic acid and antioxidant activity of five coloured bell pepper (Capsicum annum) fruits at two different harvest times. J. Funct. Foods 2011, 3, 44-49.

(32) Ou, B.; Huang, D.; Hampsch-Woodill, M.; Flanagan, J. A.; Deemer, E. K. Analysis of Antioxidant Activities of Common Vegetables Employing Oxygen Radical Absorbance Capacity (ORAC) and Ferric Reducing Antioxidant Power (FRAP) Assays: A Comparative Study. J. Agric. Food Chem. 2002, 50, 3122-3128.

(33) Sim, K. H.; Sil, H. Y. Antioxidant activities of red pepper (Capsicum annuum) pericarp and seed extracts. Int. J. Food Sci. Technol. 2008, 43, 1813-1823.

(34) Suleria, H. A. R.; Barrow, C. J.; Dunshea, F. R. Screening and Characterization of Phenolic Compounds and Their Antioxidant Capacity in Different Fruit Peels. Foods 2020, 9, 1206.

(35) Parikh, B.; Patel, V. H. Total phenolic content and total antioxidant capacity of common Indian pulses and split pulses. J. Food Sci. Technol. 2018, 55, 1499-1507.

(36) Alvarez-Parrilla, E.; de la Rosa, L. A.; Amarowicz, R.; Shahidi, F. Antioxidant Activity of Fresh and Processed Jalapeño and Serrano Peppers. J. Agric. Food Chem. 2011, 59, 163-173.

(37) Schrimpe-Rutledge, A. C.; Codreanu, S. G.; Sherrod, S. D.; McLean, J. A. Untargeted Metabolomics Strategies-Challenges and Emerging Directions. J. Am. Soc. Mass Spectrom. 2016, 27, 18971905.

(38) Rajauria, G.; Foley, B.; Abu-Ghannam, N. Identification and characterization of phenolic antioxidant compounds from brown Irish seaweed Himanthalia elongata using LC-DAD-ESI-MS/MS. Innovative Food Sci. Emerging Technol. 2016, 37, 261-268.

(39) Williamson, G.; Clifford, M. N. Colonic metabolites of berry polyphenols: the missing link to biological activity? J. Geophys. Res. Oceans 2010, 104, S48-S66.

(40) Zhang, X.; Liang, C.; Li, C.; Bu, M.; Bu, L.; Xiao, Y.; Sun, H.; Zhang, L. Simultaneous Qualitative and Quantitative Study of Main Compounds in Commelina communis Linn. by UHPLC-Q-TOF-MSMS and HPLC-ESI-MS-MS. J. Chromatogr. Sci. 2018, 56, 582-594.

(41) Saéz, V.; Riquelme, S.; Baer, D.; Vallverdú-Queralt, A. Phenolic Profile of Grape Canes: Novel Compounds Identified by LC-ESILTQ-Orbitrap-MS. Molecules 2019, 24, 3763.

(42) Spadafranca, A.; Bertoli, S.; Fiorillo, G.; Testolin, G.; Battezzati, A. Circulating salicylic acid is related to fruit and vegetable consumption in healthy subjects. J. Geophys. Res. Oceans 2007, 98, 802-806.

(43) Wang, J.; Jia, Z.; Zhang, Z.; Wang, Y.; Liu, X.; Wang, L.; Lin, R. Analysis of Chemical Constituents of Melastoma dodecandrum Lour. by UPLC-ESI-Q-Exactive Focus-MS/MS. Molecules 2017, 22, 476.

(44) Jiafei, T.; Dunshea, F. R.; Suleria, H. A. R. LC-ESI-QTOF/MS characterization of phenolic compounds from medicinal plants (hops and juniper berries) and their antioxidant activity. Foods 2020, 9, 7-7.

(45) Patras, M. A.; Jaiswal, R.; Kuhnert, N. Profiling and quantification of regioisomeric caffeoyl glucoses in Solanaceae vegetables. Food Chem. 2017, 237, 659-666.

(46) Lin, H.; Zhu, H.; Tan, J.; Wang, H.; Wang, Z.; Li, P.; Zhao, C.; Liu, J. Comparative Analysis of Chemical Constituents of Moringa oleifera Leaves from China and India by Ultra-Performance Liquid Chromatography Coupled with Quadrupole-Time-Of-Flight Mass Spectrometry. Molecules 2019, 24, 942.

(47) Meinhart, A. D.; Damin, F. M.; Caldeirao, L.; Filho, M. D. J.; Silva, L. C. D.; Constant, L. D. S.; Filho, J. T.; Wagner, R.; Godoy, H. T. Chlorogenic and caffeic acids in 64 fruits consumed in Brazil. Food Chem. 2019, 286, 51-63.

(48) Baenas, N.; Belović, M.; Ilic, N.; Moreno, D. A.; GarcíaViguera, C. Industrial use of pepper (Capsicum annum L.) derived 
products: Technological benefits and biological advantages. Food Chem. 2019, 274, 872-885.

(49) Passo Tsamo, C. V.; Herent, M.-F.; Tomekpe, K.; Happi Emaga, T.; Quetin-Leclercq, J.; Rogez, H.; Larondelle, Y.; Andre, C. M. Effect of boiling on phenolic profiles determined using HPLC/ ESI-LTQ-Orbitrap-MS, physico-chemical parameters of six plantain banana cultivars (Musa sp). J. Food Compos. Anal. 2015, 44, 158-169.

(50) Vallejo, F.; Tomas-Barberan, F. A.; Garcia-Viguera, C. Effect of climatic and sulphur fertilisation conditions, on phenolic compounds and vitamin $\mathrm{C}$, in the inflorescences of eight broccoli cultivars. Eur. Food Res. Technol. 2003, 216, 395-401.

(51) Abu-Reidah, I. M.; Arráez-Román, D.; Warad, I.; FernandezGutièrrez, A.; Segura-Carretero, A. UHPLC/MS2-based approach for the comprehensive metabolite profiling of bean (Vicia faba L.) byproducts: A promising source of bioactive constituents. Food Res. Int. 2017, 93, 87-96.

(52) Csernatoni, F.; Baciu, A.; Pop, R.; Romanciuc, F.; Socaciu, C. Characterization of Seven Medicinal Plants Included in an Original Formula Promen, To Prevent Prostate Diseases. Hop Med. Plants 2014, 1-2, 70-79.

(53) Wang, X.; Liu, J.; Zhang, A.; Sun, H.; Zhang, Y., Chapter 23Systematic Characterization of the Absorbed Components of Acanthopanax senticosus Stem. In Serum Pharmacochemistry of Traditional Chinese Medicine, Wang, X., Ed.; Academic Press, 2017; pp 313-336.

(54) Lai, K.-M.; Cheng, Y.-Y.; Tsai, T.-H. Integrated LC-MS/MS Analytical Systems and Physical Inspection for the Analysis of a Botanical Herbal Preparation. Molecules 2015, 20, 10641-10656.

(55) Thuphairo, K.; Sornchan, P.; Suttisansanee, U. Bioactive Compounds, Antioxidant Activity and Inhibition of Key Enzymes Relevant to Alzheimer's Disease from Sweet Pepper (Capsicum annuum) Extracts. Prev. Nutr. Food Sci. 2019, 24, 327-337.

(56) Adisakwattana, S. Cinnamic Acid and Its Derivatives: Mechanisms for Prevention and Management of Diabetes and Its Complications. Nutrients 2017, 9, 163.

(57) Wan, C.; Li, S.; Liu, L.; Chen, C.; Fan, S. Caffeoylquinic Acids from the Aerial Parts of Chrysanthemum coronarium L. Plants 2017, 6,10 .

(58) Kim, W. R.; Kim, E. O.; Kang, K.; Oidovsambuu, S.; Jung, S. H.; Kim, B. S.; Nho, C. W.; Um, B. H. Antioxidant activity of phenolics in leaves of three red pepper (Capsicum annuum) cultivars. J. Agric. Food Chem. 2014, 62, 850-859.

(59) Henriques, B. O.; Corrêa, O.; Azevedo, E. P. C.; Pádua, R. M.; Oliveira, V. L. S. D.; O2liveira, T. H. C.; Boff, D.; Dias, A. C. F.; Souza, D. G. D.; Amaral, F. A.; Teixeira, M. M.; Castilho, R. O.; Braga, F. C. In Vitro TNF Inhibitory Activity of Brazilian Plants and Anti-Inflammatory Effect of Stryphnodendron adstringens in an Acute Arthritis Model. Evidence-Based Complementary Altern. Med. 2016, 2016, No. 9872598.

(60) Lee, L. S.; Kim, S. H.; Kim, Y. B.; Kim, Y. C. Quantitative analysis of major constituents in green tea with different plucking periods and their antioxidant activity. Molecules 2014, 19, 9173-9186.

(61) Grzesik, M.; Naparło, K.; Bartosz, G.; Sadowska-Bartosz, I. Antioxidant properties of catechins: Comparison with other antioxidants. Food Chem. 2018, 241, 480-492.

(62) Enomoto, H.; Takahashi, S.; Takeda, S.; Hatta, H. Distribution of Flavan-3-ol Species in Ripe Strawberry Fruit Revealed by MatrixAssisted Laser Desorption/Ionization-Mass Spectrometry Imaging. Molecules 2019, 25, 103.

(63) Tsanova-Savova, S.; Ribarova, F.; Gerova, M. (+)-Catechin and (-)-epicatechin in Bulgarian fruits. J. Food Compos. Anal. 2005, 18, 691-698.

(64) Medina-Juárez, L. Á.; Molina-Quijada, D. M. A.; Toro-Sánchez, C. L. D.; González-Aguilar, G. A.; Gámez-Meza, N. Antioxidant activity of peppers (Capsicum annuum L.) extracts and characterization of their phenolic constituents. Interciencia 2012, 37, 588-593.

(65) Yang, Y.; Zhao, X. J.; Pan, Y.; Zhou, Z. Identification of the chemical compositions of Ponkan peel by ultra performance liquid chromatography coupled with quadrupole time-of-flight mass spectrometry. Anal. Methods 2016, 8, 893-903.

(66) Alam, M. A.; Subhan, N.; Rahman, M. M.; Uddin, S. J.; Reza, H. M.; Sarker, S. D. Effect of citrus flavonoids, naringin and naringenin, on metabolic syndrome and their mechanisms of action. Adv. Nutr. 2014, 5, 404-417.

(67) Zeng, S. L.; Liu, X. G.; Lai, C. J.; Liu, E. H.; Li, P. Diagnostic ion filtering strategy for chemical characterization of Guge Fengtong Tablet with high-performance liquid chromatography coupled with electrospray ionization quadrupole time-of-flight tandem mass spectrometry. Chin. J. Nat. Med. 2015, 13, 390-400.

(68) Singh, A.; Kumar, S.; Bajpai, V.; Reddy, T. J.; Rameshkumar, K. B.; Kumar, B. Structural characterization of flavonoid C- and Oglycosides in an extract of Adhatoda vasica leaves by liquid chromatography with quadrupole time-of-flight mass spectrometry. Rapid Commun. Mass Spectrom. 2015, 29, 1095-1106.

(69) Wang, M.; Firrman, J.; Liu, L.; Yam, K. A Review on Flavonoid Apigenin: Dietary Intake, ADME, Antimicrobial Effects, and Interactions with Human Gut Microbiota. BioMed Res. Int. 2019, 2019, No. 7010467.

(70) Salehi, B.; Venditti, A.; Sharifi-Rad, M.; Kręgiel, D.; Sharifi-Rad, J.; Durazzo, A.; Lucarini, M.; Santini, A.; Souto, E. B.; Novellino, E.; Antolak, H.; Azzini, E.; Setzer, W. N.; Martins, N. The Therapeutic Potential of Apigenin. Int. J. Mol. Sci. 2019, 20, 1305.

(71) Wahyuni, Y.; Ballester, A. R.; Sudarmonowati, E.; Bino, R. J.; Bovy, A. G. Secondary metabolites of Capsicum species and their importance in the human diet. J. Nat. Prod. 2013, 76, 783-793.

(72) Feng, W.; Dong, Q.; Liu, M.; Li, S.; Liu, T.; Wang, X.; Niu, L. Screening and identification of multiple constituents and their metabolites of Zhi-zi-chi decoction in rat urine and bile by ultrahigh-performance liquid chromatography quadrupole time-of-flight mass spectrometry. Biomed. Chromatogr. 2017, 31, e3978.

(73) Dixon, R. A.; Pasinetti, G. M. Flavonoids and Isoflavonoids: From Plant Biology to Agriculture and Neuroscience. Plant Physiol. 2010, 154, 453.

(74) Hussain, F.; Jahan, N. Identification of Hypotensive Biofunctional Compounds of $\langle i>$ Coriandrum sativum $</ i>$ and Evaluation of Their Angiotensin-Converting Enzyme (ACE) Inhibition Potential. Oxid. Med. Cell. Longevity 2018, 2018, No. 4643736.

(75) Te-Sheng, C. Isolation, bioactivity, and production of orthohydroxydaidzein and ortho-hydroxygenistein. 2014, 15, 5699-5716, DOI: $10.3390 /$ ijms 15045699 .

(76) Yang, L.; Li, A.; Chen, M.; Yan, Y.; Liu, Y.; Li, K.; Jia, J.; Qin, X. Comprehensive investigation of mechanism and effective ingredients of Fangji Huangqi Tang by serum pharmacochemistry and network pharmacology. Biomed. Chromatogr. 2020, 34, e4785.

(77) Petkovska, A.; Gjamovski, V.; Stanoeva, J. P.; Stefova, M. Characterization of the Polyphenolic Profiles of Peel, Flesh and Leaves of Malus domestica Cultivars Using UHPLC-DAD-HESI-MS. Nat. Prod. Commun. 2017, 12, 35-42.

(78) Ivanova, V.; Dörnyei, A.; Márk, L.; Vojnoski, B.; Stafilov, T.; Stefova, M.; Kilár, F. Polyphenolic content of Vranec wines produced by different vinification conditions. Food Chem. 2011, 124, 316-325.

(79) Xu, L.; Liu, Y.; Wu, H.; Wu, H.; Liu, X.; Zhou, A. Rapid identification of chemical profile in Gandou decoction by UPLC-QTOF-MSE coupled with novel informatics UNIFI platform. J. Pharm. Anal. 2020, 10, 35-48.

(80) Jayaprakasha, G. K.; Jaganmohan Rao, L.; Sakariah, K. K. Antioxidant activities of curcumin, demethoxycurcumin and bisdemethoxycurcumin. Food Chem. 2006, 98, 720-724.

(81) Lu, Q.-Y.; Summanen, P. H.; Lee, R.-P.; Huang, J.; Henning, S. M.; Heber, D.; Finegold, S. M.; Li, Z. Prebiotic Potential and Chemical Composition of Seven Culinary Spice Extracts. J. Food Sci. 2017, 82, 1807-1813.

(82) Carvalho Lemos, V.; Reimer, J. J.; Wormit, A. Color for Life: Biosynthesis and Distribution of Phenolic Compounds in Pepper (Capsicum annuum). Agriculture 2019, 9, 81.

(83) Wang, Y.; Han, F.; Song, A.; Wang, M.; Zhao, M.; Zhao, C. Rapid characterization of the chemical constituents of Cortex Fraxini 
by homogenate extraction followed by UHPLC coupled with Fourier transform ion cyclotron resonance mass spectrometry and GC-MS. J. Sep. Sci. 2016, 39, 4325-4334.

(84) Drira, M.; Kelebek, H.; Guclu, G.; Jabeur, H.; Selli, S.; Bouaziz, $\mathrm{M}$. Targeted analysis for detection the adulteration in extra virgin olive oil's using LC-DAD/ESI-MS/MS and combined with chemometrics tools. Eur. Food Res. Technol. 2020, 246, 1661-1677.

(85) Di Maio, I.; Esposto, S.; Taticchi, A.; Selvaggini, R.; Veneziani, G.; Urbani, S.; Servili, M. Characterization of 3,4-DHPEA-EDA oxidation products in virgin olive oil by high performance liquid chromatography coupled with mass spectrometry. Food Chem. 2013, $138,1381-1391$.

(86) Wang, Y.; Vorsa, N.; Harrington, P. D. B.; Chen, P. Nontargeted Metabolomic Study on Variation of Phenolics in Different Cranberry Cultivars Using UPLC-IM - HRMS. J. Agric. Food Chem. 2018, 66, 12206-12216.

(87) Zhang, Q. Q.; Dong, X.; Liu, X. G.; Gao, W.; Li, P.; Yang, H. Rapid separation and identification of multiple constituents in Danhong Injection by ultra-high performance liquid chromatography coupled to electrospray ionization quadrupole time-of-flight tandem mass spectrometry. Chin. J. Nat. Med. 2016, 14, 147-160.

(88) Yang, S.; Shan, L.; Luo, H.; Sheng, X.; Du, J.; Li, Y. Rapid Classification and Identification of Chemical Components of Schisandra Chinensis by UPLC-Q-TOF/MS Combined with Data Post-Processing. Molecules 2017, 22, 1178.

(89) Reed, K. A. In Identification of Phenolic Compounds from Peanut Skin using HPLC-MSn, 2009.

(90) Kumar, O.; Rao, S.; Tata, S. Phenolics Quantification in Some Genotypes of Capsicum annuum L. J. Phytol. 2010, 2, 87-90.

(91) Sayin, F. K. Anti-Hyperglycaemic Activity and Antioxidant Properties of Pepper Waste and Fruit. J. Biotechnol. Biochem. 2016, 2, 22-27.

(92) Sandoval-Castro, C. J.; Valdez-Morales, M.; Oomah, B. D.; Gutiérrez-Dorado, R.; Medina-Godoy, S.; Espinosa-Alonso, L. G. Bioactive compounds and antioxidant activity in scalded Jalapeño pepper industrial byproduct (Capsicum annuum). J. Food Sci. Technol. 2017, 54, 1999-2010.

(93) Chen, L.; Kang, Y.-H. Anti-inflammatory and antioxidant activities of red pepper (Capsicum annuum L.) stalk extracts: Comparison of pericarp and placenta extracts. J. Funct. Foods 2013, 5, 1724-1731.

(94) Zhang, D.; Hamauzu, Y. Phenolic compounds, ascorbic acid, carotenoids and antioxidant properties of green, red and yellow bell peppers. J. Food, Agric. Environ. 2002, 1, 22-27.

(95) Gu, C.; Howell, K.; Dunshea, F. R.; Suleria, H. A. R. LC-ESIQTOF/MS Characterisation of Phenolic Acids and Flavonoids in Polyphenol-Rich Fruits and Vegetables and Their Potential Antioxidant Activities. Antioxidants 2019, 8, 405.

(96) Zou, B. Development of suitable standards for quantitative determination of persimmon phenol contents in Folin-Ciocalteu and vanillin assays. Eur. Food Res. Technol. 2014, 239, 385-391.

(97) Ma, C.; Dunshea, F. R.; Suleria, H. A. R. LC-ESI-QTOF/MS Characterization of Phenolic Compounds in Palm Fruits (Jelly and Fishtail Palm) and Their Potential Antioxidant Activities. Antioxidants 2019, 8, 483.

(98) Benzie, I. F.; Strain, J. J. The ferric reducing ability of plasma (FRAP) as a measure of "antioxidant power": the FRAP assay. Anal. Biochem. 1996, 239, 70-76.

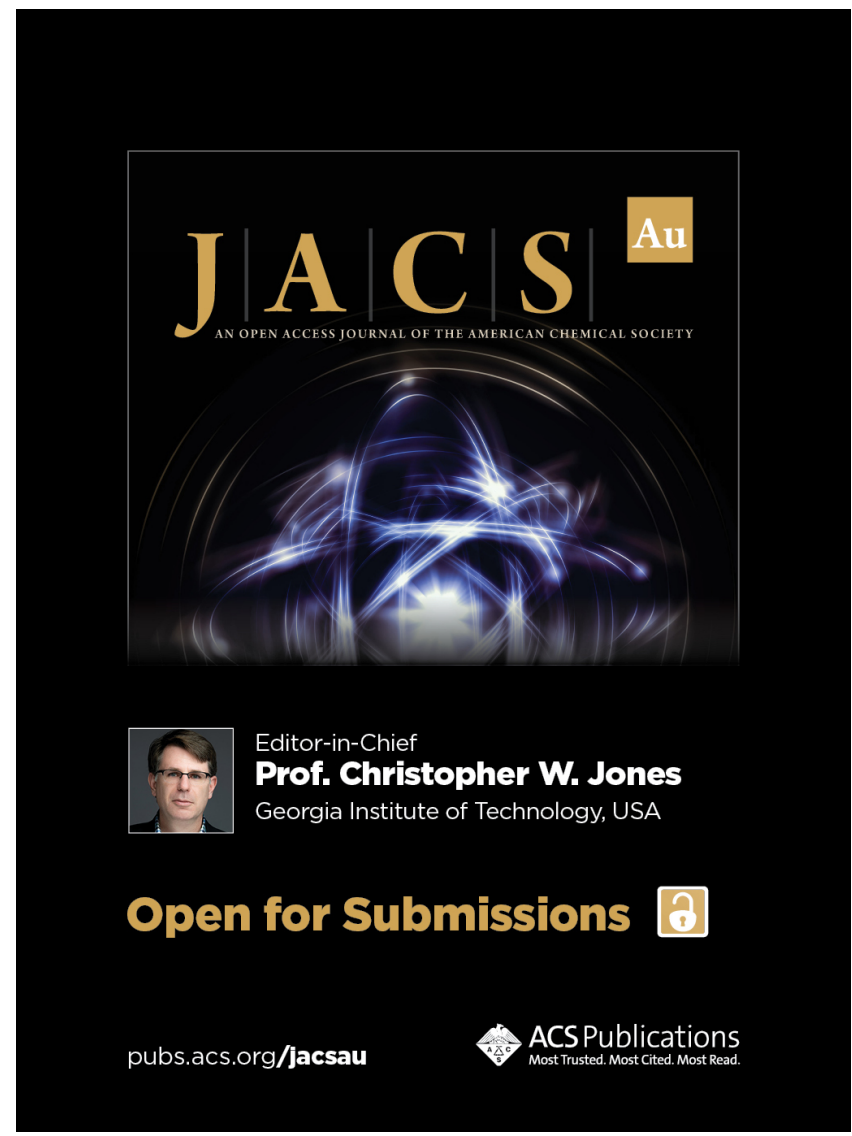




\section{University Library}

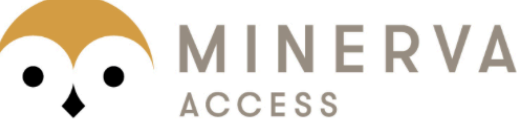

A gateway to Melbourne's research publications

Minerva Access is the Institutional Repository of The University of Melbourne

\section{Author/s:}

Leng, Z;Zhong, B;Wu, H;Liu, Z;Rauf, A;Bawazeer, S;Suleria, HAR

Title:

Identification of Phenolic Compounds in Australian-Grown Bell Peppers by Liquid Chromatography Coupled with Electrospray Ionization-Quadrupole-Time-of-Flight-Mass Spectrometry and Estimation of Their Antioxidant Potential

Date:

2022

Citation:

Leng, Z., Zhong, B., Wu, H., Liu, Z., Rauf, A., Bawazeer, S. \& Suleria, H. A. R. (2022). Identification of Phenolic Compounds in Australian-Grown Bell Peppers by Liquid Chromatography Coupled with Electrospray Ionization-Quadrupole-Time-of-FlightMass Spectrometry and Estimation of Their Antioxidant Potential. ACS Omega, 7 (5), pp.4563-4576. https://doi.org/10.1021/acsomega.1c06532.

Persistent Link:

http://hdl.handle.net/11343/297281

License:

CC BY-NC-ND 